\title{
Efficient aqueous remote loading of peptides in poly(lactic-co-glycolic acid)
}

\section{Morgan Giles}

University of Michigan-Ann Arbor https://orcid.org/0000-0001-6716-6599

\section{Justin Hong}

University of Michigan-Ann Arbor https://orcid.org/0000-0003-0403-6679

\section{Yayuan Liu}

University of Michigan

Jie Tang

University of Michigan-Ann Arbor

\section{Tinghui Li}

University of Michigan-Ann Arbor

\section{Avital Beig}

University of Michigan-Ann Arbor

\section{Anna Schwendeman}

University of Michigan

Steven Schwendeman ( $\square$ schwende@umich.edu )

University of Michigan

\section{Article}

Keywords: Poly(lactic-co-glycolic acid) (PLGA), peptide drugs, encapsulation strategies

Posted Date: March 10th, 2021

DOI: https://doi.org/10.21203/rs.3.rs-294137/v1

License: (c) (1) This work is licensed under a Creative Commons Attribution 4.0 International License.

Read Full License 
Efficient aqueous remote loading of peptides in poly(lactic-co-glycolic acid)

Morgan B. Giles ${ }^{1}$, Justin K.Y. Hong ${ }^{1}$, Yayuan Liu ${ }^{1}$, Jie Tang ${ }^{1}$, Tinghui Li ${ }^{1}$, Avital Beig ${ }^{1}$, Anna Schwendeman ${ }^{1}$ and Steven P. Schwendeman ${ }^{1,2^{*}}$

1. Department of Pharmaceutical Sciences and the Biointerfaces Institute, University of Michigan, North Campus Research Complex, 2800 Plymouth Road, Ann Arbor, MI 48109, USA

2. Department of Biomedical Engineering, University of Michigan, 2200 Bonisteel Blvd, Ann Arbor, Ml 48109, USA

*Corresponding author. Email address: schwende@umich.edu 


\section{Abstract}

Poly(lactic-co-glycolic acid) (PLGA) long-acting release (LAR) depots are effective for extending the duration of action of peptide drugs. New market approvals have been slow with dated organic-solvent-based microencapsulation approaches. We describe efficient organic-solventfree remote encapsulation based on the capacity of common acid-capped PLGA to bind, and absorb into the polymer phase, net positively charged peptides in aqueous solution after short exposure at modest temperature. Leuprolide encapsulated by this approach in low-molecularweight PLGA 75/25 microspheres slowly and continuously released peptide for over 56 days in vitro and suppressed testosterone production in rats in an equivalent manner as the 1-month Lupron Depot $\circledast$. The technique is generalizable to encapsulate a number of net cationic peptides of various size, including octreotide, with competitive loading and encapsulation efficiencies to traditional techniques. In certain cases, in vitro and in vivo performance of remote-loaded PLGA microspheres exceeded that relative to marketed products and displayed important features not currently possible with existing encapsulation strategies. 


\section{Introduction}

Peptide drugs with molecular weights from a few hundred to a few thousand Daltons form a unique class of drugs with both unique mechanisms of pharmacological action and physical-chemical properties. ${ }^{1}$ Once beyond a few amino acids peptides are often difficult to deliver to the body owing to poor bioavailability by noninvasive routes of drug administration and short serum half-lives. ${ }^{2}$ Two common methods to improve systemic exposure and minimize injections of peptides include half-life extension via covalent modification and microencapsulation in biodegradable PLGA., ${ }^{3,4}$ Microencapsulation has the advantages of much longer intervals between injections ( $>$ weeks to months) and that no new active pharmaceutical ingredient (API) needs to be developed, which has fewer regulatory obstacles.

However, after the initial peptide/PLGA LAR products were developed in the late 1980s few new peptide APIs have appeared in these formulations ${ }^{5,6}$ and generic PLGA LARs have thus far not reached the US market. ${ }^{7}$ One important factor involves the limitations of the current microencapsulation approaches applied to create injectable LARs, with microspheres (approx. $1-100 \mu \mathrm{m}$ in size) being the most common configuration used. Less common solid cylindrical and in-situ forming PLGA LARs are also available. ${ }^{8}$ Conventional microencapsulation approaches to manufacture PLGA microspheres include solvent evaporation, coacervation, and spray-drying. In each of these methods the API is combined with a PLGA dissolved in an organic solvent before forming microspheres. This dated combination creates a number of undesirable issues: (a) the peptide-loaded microspheres most often cannot be terminally sterilized requiring expensive aseptic processing with organic solvents and numerous unit operations; (b) the API is expensive and therefore it is undesired to discard poorly formed drug-polymer microspheres (tiny fines, large aggregated microspheres, or debris on mixing equipment) and yields can be far less than $100 \%$; (c) the complexity of unit operations and components necessary to form microspheres can be problematic to scale-up to large-scale manufacture; (d) some products have multiple residual organic solvents and water, which pose challenges to storage stability of the final product; ${ }^{9}$ (e) there is little opportunity to manipulate the polymer structure to attenuate release kinetics once the peptide-PLGA 
matrix is formed limiting the ability to engineer release kinetics, ${ }^{10,11}$ and (f) mixing organic solvent/water mixtures in the presence of peptides, particularly with higher-order structure, can be detrimental to drug stability. ${ }^{12}$

Mechanistic analysis of peptide/PLGA interactions revealed a plausible solution to many of the above difficulties. Recently we discovered that two of the peptides currently used in PLGA LARs, leuprolide and octreotide, long known to bind to the surface of acid-capped PLGA (PLGA-COOH), can in fact be absorbed rapidly into the polymer phase of PLGA-COOH at high drug content with peptide desorption slow enough for potential controlled release. ${ }^{13}$ Remote loading based on absorption in the polymer phase is very different from a prior technique ${ }^{14}$ where macromolecular drugs including peptides can be encapsulated by self-healing (or closing) of the aqueous pores in typical aliphatic ester end-capped PLGAs, which do not bind and significantly absorb peptides into the polymer phase. ${ }^{13,15}$ In initial studies drug encapsulation by absorption was highly inefficient and release kinetics undesirable. ${ }^{13}$ Here we describe a self-encapsulating PLGA microsphere, formulated from the same PLGA 75/25 employed in the well-known 1-month Lupron Depot ${ }^{\circledR}$, which can be mixed with modest aqueous peptide solutions rapidly to form highly desirable peptide LARs. These formulations are capable of encapsulating a number of peptides at high efficiency and high drug loading and release the drug continuously with acceptable initial burst release in vitro and in vivo. The clear advantage of the approach is the capability to adjust the properties of the polymer (e.g., size distribution, porosity, residual organic solvent) and to terminally sterilize the microspheres (e.g., via gamma irradiation) allowing more control of product performance and reduced costs during a simple aqueous mixing step. Additionally, similar to use of remote loading liposomes ${ }^{16}$ and commercial transfecting agents, ${ }^{17,18}$ sterile pre-formed microspheres are capable of encapsulating peptides by the user at essentially $100 \%$ yields and with far less peptide needed compared to conventional encapsulation methods where even bench-scale procedures often require tens of milligrams of drug.

Giles et al. 


\section{Results and Discussion}

To demonstrate the approach, we mixed sieved drug-free PLGA 75/25 microspheres (20 - $63 \mu \mathrm{m})$ with and without prior gamma irradiation at high microsphere concentration $(180-240 \mathrm{mg} / \mathrm{ml})$ with leuprolide, octreotide, and several other peptides $(20 \mathrm{mg} / \mathrm{ml})$ in a neutral $\mathrm{pH}$ HEPES buffer solution under mild agitation for $24 \mathrm{~h}$ at $37^{\circ} \mathrm{C}$ (Fig 1 and Supplementary Fig 1).
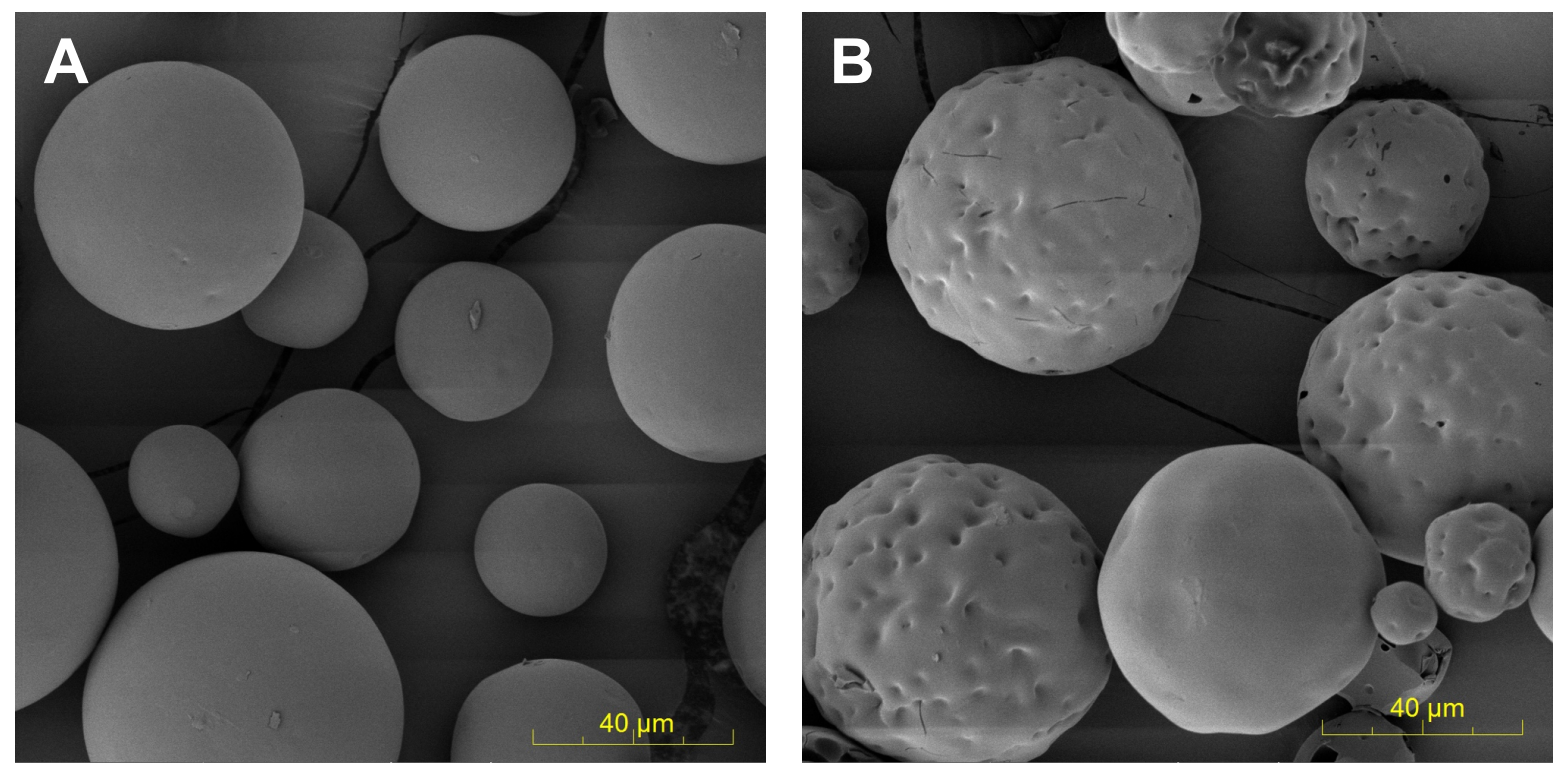

Figure 1. Scanning electron micrographs of (A) blank PLGA Microspheres and (B) the blank microspheres remote-loaded with octreotide.

Microspheres were collected by centrifugation washed and lyophilized. All microspheres were suspendable with retention of near spherical shape after peptide loading. For leuprolide, the microspheres loaded $6.63 \pm 0.10$ to $9.37 \pm 0.03 \% \mathrm{w} / \mathrm{w}$ peptide at $66-94 \%$ efficiency (Supplementary Table 1) and slowly released leuprolide over 4 weeks in a PBS buffer in a similar manner, and with comparable burst release after 1 day $(28.8-34.3 \%)$ (Supplementary Fig 2), as the 1-month Lupron Depot ${ }^{\circledR}$ (Fig. 2A and Supplementary Figure 2). Remote-loaded microspheres exhibited some small cracks (Fig 1B and Supplementary Figure 1C), likely owing to polymer rearrangement to accommodate the loaded peptide and the strong neutral $\mathrm{pH}$ buffer in the loading media, although this feature did not adversely affect microsphere performance (see below). 


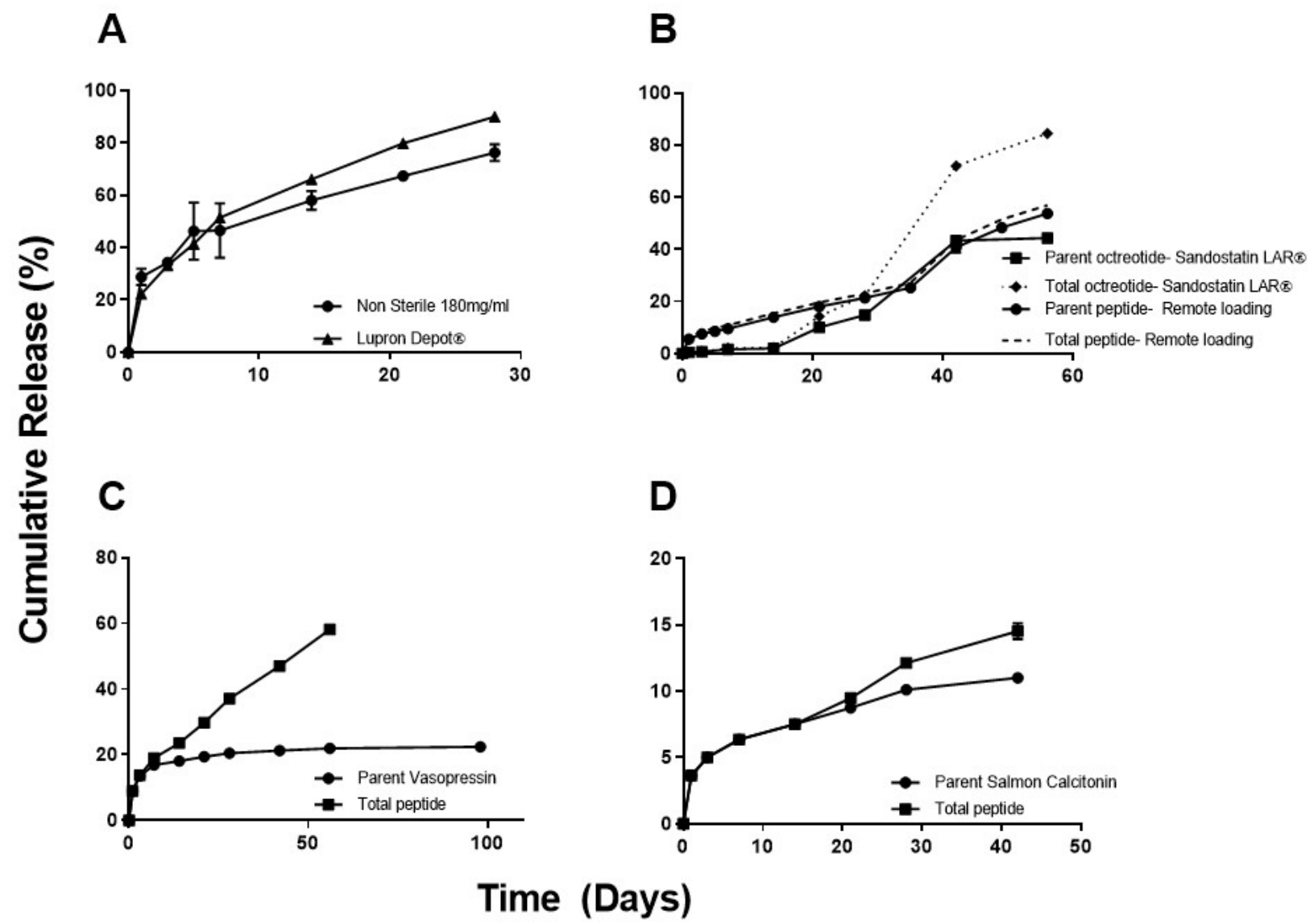

Figure 2. Cumulative in vitro drug release from remote-loaded PLGA microspheres for (A) leuprolide compared to Lupron Depot $\AA$, (B) octreotide compared to Sandostatin LAR® (SLAR), (C) vasopressin, and (D) salmon calcitonin. All remote-loaded microspheres were from non-sterile blank PLGA and from $180 \mathrm{mg} / \mathrm{ml}$ peptide solution. Parent and total peptide release listed for specific peptides not fully stable in the polymer. SLAR control data from Beig et al. ${ }^{19}$

The leuprolide/PLGA microspheres were also administered to rats every 4 weeks for 3 months and compared for testosterone suppression in rats relative to the Lupron Depot ${ }^{\circledR}$. After stimulating the downregulation of the gonadotropin-releasing hormone receptor, the animals receiving each of the formulations displayed sustained castration indistinguishable from that of the 1-month Lupron Depot

(Figs. 3 and S5). Injection of negative control groups, either soluble peptide or drug-free PLGA particulate, are incapable of sustaining plasma testosterone below castration levels $(0.5 \mathrm{ng} / \mathrm{mL})^{13}$ necessary to minimize signaling of hormone dependent cancer cell growth. ${ }^{20}$ 


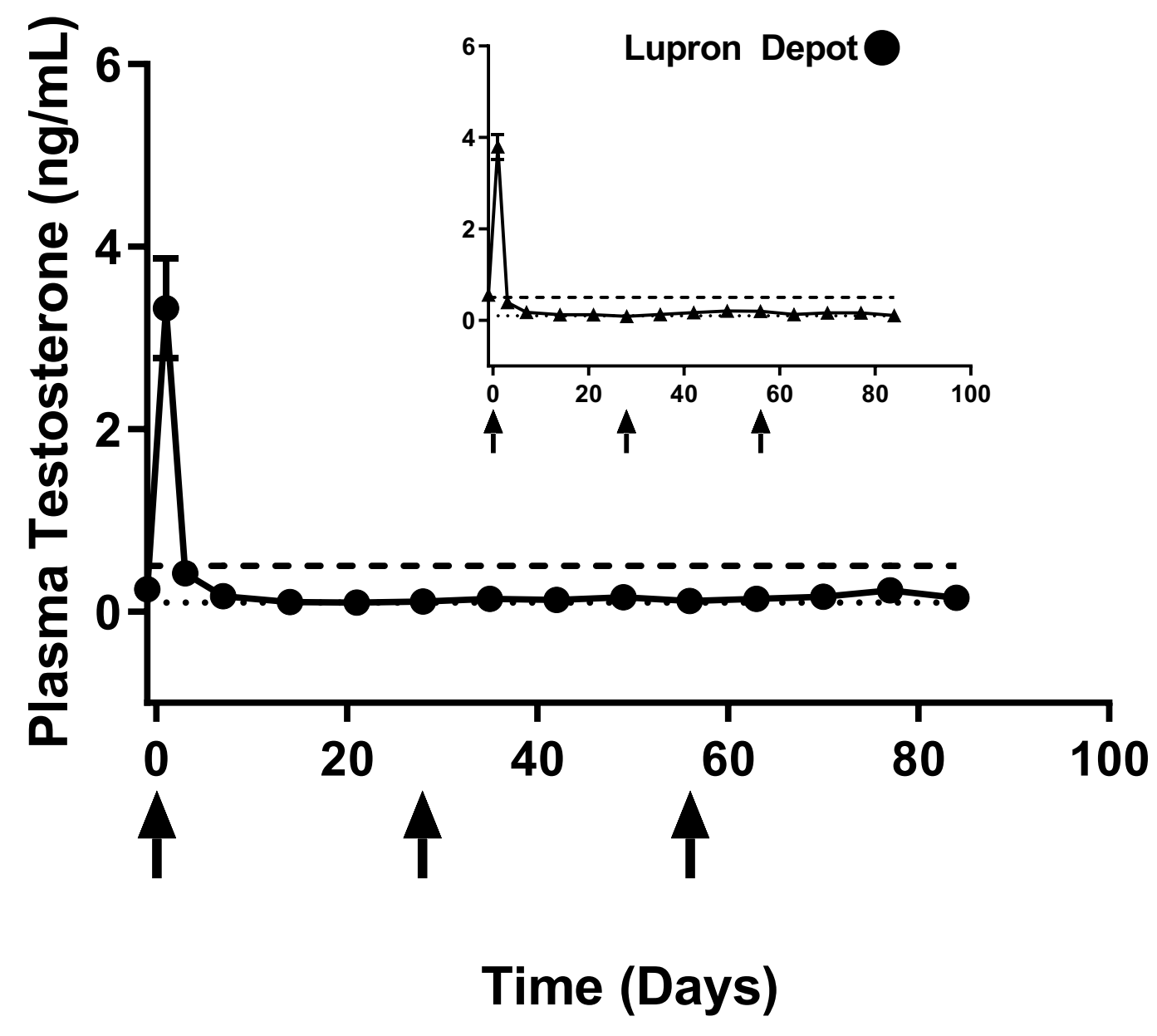

Figure 3. In vivo plasma testosterone levels of male Sprague-Dawley rats administered 3 monthly doses of remote-loaded leuprolide PLGA microspheres compared to equivalent 1-month Lupron Depot ${ }^{\circledR}$ administration (inset). Dashed line indicates castration level $(0.5 \mathrm{ng} / \mathrm{mL})$. Dotted line indicates analysis limit of quantitation $(0.1 \mathrm{ng} / \mathrm{mL})$. Mean $\pm S E M(n=6)$. Arrow indicates days of dosing. Remote-loaded microspheres were from $240 \mathrm{mg} / \mathrm{mL}$ leuprolide in PLGA microspheres previously exposed to gamma irradiation.

To explore the generality of the approach we encapsulated several additional peptides under the same conditions as optimized with leuprolide and with the same drug-free microspheres. Strongly positively charged peptides (leuprolide, exenatide, salmon calcitonin and pramlintide) were all encapsulated at high efficiency (68-98\%) and loading (6.8-9.8\% w/w) in contrast with net negatively charged exenatide (23\% efficiency, $\mathrm{pI}=4.9^{21}$ and mostly neutral protirelin (28\% efficiency, single ionizable His residue) (Table 1, Supplementary Table 1). Consistent with these results molar free energy of the peptide-PLGACOOH binding determined in DMSO by isothermal titration calorimetry (ITC) (Fig. 4) was strongly 
favorable with stoichiometric coefficients of 0.32-0.94 mole/mole peptide/PLGA-COOH group (Table 1).
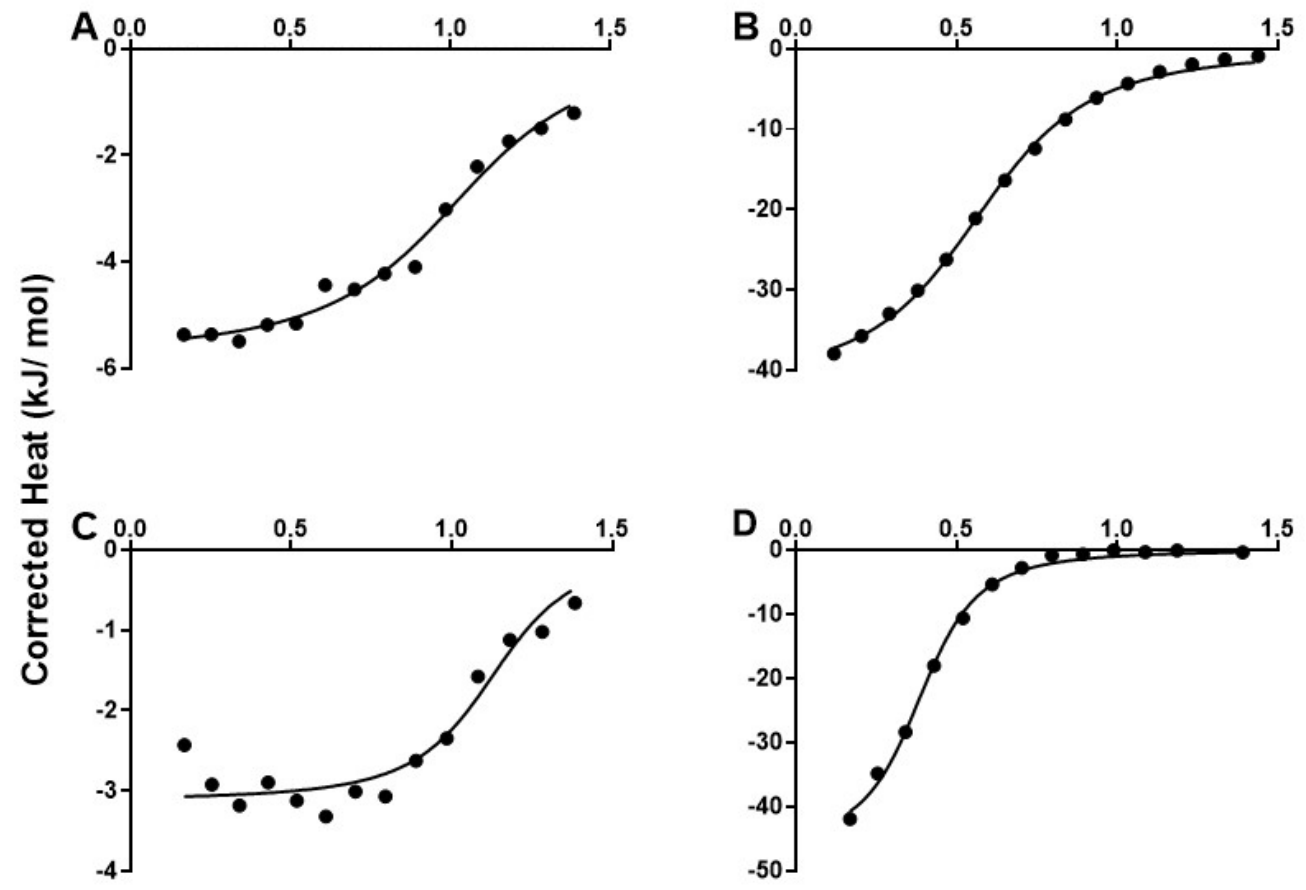

\section{Moles Peptide/ Moles PLGA-COOH}

Figure 4. ITC thermograms of the binding of leuprolide (A), octreotide (B), vasopressin (C), and salmon calcitonin (D) to $75 / 25$ PLGA-COOH in DMSO. Data shown as heat released per molar ratio of peptide to-COOH groups of PLGA.

ITC curve fitting predicted binding as enthalpically favored for peptides with primary amines (Lys side chains and free $\mathrm{N}$-terminus in octreotide and calcitonin) indicative of strongly favorable intermolecular forces (e.g., combination of ionic and H-bonding interactions). ${ }^{22,23}$ Entropically driven binding was determined for peptides with cationic Arg residues but no amino groups (leuprolide and vasopressin), indicative of desolvation-driven interactions. ${ }^{24}$ Cationic pramlintide with significant higher order structure $^{25}$ also displayed high loading (9.8\%) and binding to PLGA-COOH via ITC (Fig. S4), although binding showed some anomalous behavior prohibiting estimates of binding energies. Exenatide and 
protirelin displayed very low binding tendencies, as expected by their absence of positive charge (Fig. S4).

Table 1.Peptide-PLGA binding parameters by isothermal titration calorimetry at $37^{\circ} \mathrm{C}$ in DMSO and efficiency of remote loading in PLGA 75/25 microspheres by absorption at 1 day at $37^{\circ} \mathrm{C}$.

\begin{tabular}{|c|c|c|c|c|c|c|c|}
\hline Peptide & $\begin{array}{c}\text { Association } \\
\text { Constant } \\
\left(\mathrm{mM}^{-1}\right)\end{array}$ & $\begin{array}{l}\text { Stoichio- } \\
\text { metry }\end{array}$ & $\Delta \mathrm{H}(\mathrm{kJ} / \mathrm{mol})$ & $\Delta \mathrm{S}(\mathrm{kJ} / \mathrm{mol} \cdot \mathrm{K})$ & $\Delta G(\mathrm{~kJ} / \mathrm{mol})$ & Loading (\%) & $\begin{array}{l}\text { Encapsulation } \\
\text { efficiency (\%) }\end{array}$ \\
\hline Leuprolide & 17.61 & 1.0 & -5.72 & .063 & -25.21 & $9.65 \pm 0.01$ & $96.5 \pm 0.1$ \\
\hline Octreotide & 13.33 & .59 & -41.73 & -.056 & -24.49 & $6.80 \pm 0.12$ & $67.9 \pm 1.2$ \\
\hline Vasopressin & 53.10 & 1.1 & -3.12 & .080 & -28.06 & $8.00 \pm 0.32$ & $86.6 \pm 3.4$ \\
\hline Salmon Calcitonin & 31.41 & .37 & -46.41 & -.064 & -26.70 & $8.20 \pm 0.66$ & $80.8 \pm 5.0$ \\
\hline
\end{tabular}

As with leuprolide, the 1-day remote absorption encapsulation procedure yielded PLGA microspheres that slowly released cationic peptides. Octreotide was released for $>8$ weeks after remote loading by desirable zero-order kinetics with minimal peptide instability, in contrast with the existing 1-month

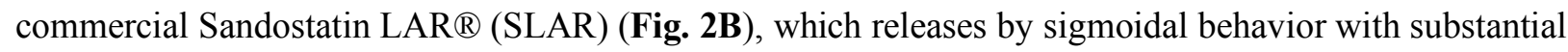
peptide acylation and loss of parent drug. Vasopressin and salmon calcitonin were also slowly and continuously released (Figs. 2C and 2D), with the former showing behavior consistent with peptide damage ${ }^{12}$ in the PLGA carrier and the latter only releasing $<20 \%$ parent peptide. The low level of salmon calcitonin release was found to be consistent with the instability of the drug in the release media (Supplementary Table 2). It is noted here that it is well known that certain peptides encapsulated in the commercial formulations display significant peptide instability (e.g., octreotide in SLAR ${ }^{19}$ and exenatide in Bydureon ${ }^{\circledR}$, data not shown ${ }^{26}$ ) and no attempt was made to introduce excipients to minimize these reactions. The presence of primary amino groups (as found in octreotide and calcitonin) are well established to lead to peptide acylation products consisting of adducts mostly from glycolic and lactic acid monomers and dimers, ${ }^{15,27}$ which is consistent with reduction in bioavailability of the SLAR relative to the free peptide injection. ${ }^{28}$ Leuprolide possesses a positive charge at neutral $\mathrm{pH}$ from its arginine residue without any primary amino groups and displays negligible instability in PLGA. Therefore, peptide release data (Figs. 2A, S2, and S3) for leuprolide represents that of parent drug. 
In order to verify that the slow-release behavior for the additional peptides recorded under in vitro conditions was also observed in vivo, we evaluated the pharmacokinetics in rats of octreotide and salmon calcitonin remote-loaded microspheres. In addition, in place of vasopressin, which was also likely damaged by the erosion of PLGA, we also encapsulated another cationic peptide, bremelanotide, a recently FDA approved hormone indicated for generalized hypoactive sexual desire disorder (HSDD) in premenopausal women ${ }^{29}$. Remote-loaded microspheres of this latter peptide exhibited elevated encapsulation efficiency $(83.7 \% \pm 0.7)$ and a slightly higher burst than leuprolide or octreotide before steadily releasing for just over 4 weeks in vitro (Fig. S6). As expected, single subcutaneous injections of microspheres elevated the plasma concentration of each of the peptide for 3-6 weeks as predicted by the corresponding in vitro release kinetics. Most interesting was the systemic exposure of remote-loaded octreotide relative to commercial Sandostatin LAR (SLAR). Relative to SLAR, which is formulated by the highly complex coacervation method in a glucose-star PLGA ${ }^{30}$, the remote-loaded formulation exhibited more continuous plasma levels without a lag time and with as high or higher relative bioavailability (i.e., as indicated by the similar area under the plasma concentration-time curves, $6460 \pm$ $560 \mathrm{ng} \cdot \mathrm{hr} / \mathrm{ml}$ vs. $7640 \pm 1040 \mathrm{ng} \cdot \mathrm{hr} / \mathrm{ml}$, for SLAR and remote-loaded octreotide, respectively) (Fig. 5). There was no significant difference in AUCs for these two formulations. Both bremelanotide and salmon calcitonin have very short plasma half-lives in rats $(<1 \mathrm{~h}),{ }^{31,32}$ confirming that the remote-loaded formulations retain these peptides for weeks after administration. As each of the peptide possess different physical-chemical and biological properties, optimal in vitro and in vivo performance, as originally developed for leuprolide for the remote-loading formulation described here may need to be adjusted depending on the desired release and stability behavior for the specific peptide of interest. 

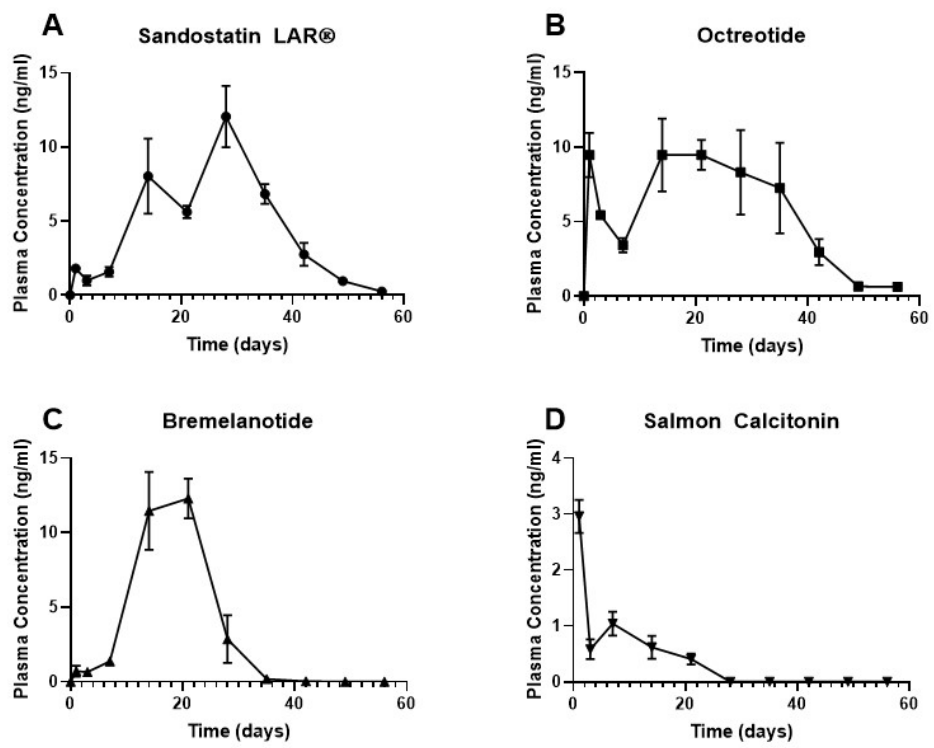

Figure 5. Pharmacokinetics after single subcutaneous injections of Sandostatin LAR $®(A)$, and remote-loaded microspheres containing octreotide (B), bremelanotide (C) and salmon calcitonin (D) in male Sprague-Dawley rats. Rats in the octreotide and bremelanotide groups were administered a dose of $18 \mathrm{mg} / \mathrm{kg}$. Rats in the salmon calcitonin group were dosed at $4 \mathrm{mg} / \mathrm{kg}$. Mean \pm $\operatorname{SEM}(n=4)$.

Few scalable microencapsulation methods for microsphere preparation are available ${ }^{33,34}$ and only a few new encapsulation techniques have been introduced with a clear path to commercialization. A spray congealing approach was developed to be compatible with fragile proteins such as human growth hormone and advanced to the FDA approved Nutropin Depot. ${ }^{35,36}$ However, this product had issues such as high initial burst release kinetics and was removed from the market several years after its approval. ${ }^{35,37}$ We have previously introduced the concept of remote loading in aqueous solution ${ }^{14,38}$ by encapsulating large molecules including leuprolide and large proteins in porous aliphatic ester end-capped PLGAs, where pores are closed spontaneously by passive healing of the polymer with elevated temperature. This technique, devised to avoid micronization of proteins and their contact with organic solvent, currently requires a "trapping agent" to be placed inside the polymer pores to bind the entering drug to avoid low encapsulation efficiency (e.g., $<13 \%$ for leuprolide in end-capped PLGA). ${ }^{14}$ The acid-capped polymer used here owing to its more hydrophilic end groups does not heal particularly well in comparison with 
ester-end-capped PLGAs ${ }^{14,39}$ and does not need a trapping agent as the carboxylic acid group initiates peptide entry into the polymer phase. As with self-healing encapsulation, remote loading by absorption requires that the loading temperature is held above the hydrated glass transition temperature $\left(\mathrm{T}_{\mathrm{g}}\right)$ of the polymer. For example, dry and hydrated $\mathrm{T}_{\mathrm{g}}$ of PLGA 75/25 microspheres used for loading peptides is $46.3 \pm 0.1{ }^{\circ} \mathrm{C}$ and $30.3 \pm 0.4{ }^{\circ} \mathrm{C}$, before loading, respectively, allowing for adequate mobility of the PLGA-COOH solid solution at $37{ }^{\circ} \mathrm{C}$ for peptide entry. ${ }^{15}$ This unique absorption and continuous release characteristic of low molecular weight PLGA-COOHs such as used in the Lupron Depot ${ }^{40,41}$ makes the current remote-loading method much simpler and readily scalable for use with small peptides. For large proteins where polymer-peptide interactions are not desired, the self-healing approach is warranted. It is noteworthy that remote loading is expected to be compatible with newer approaches toward producing PLGA microspheres that control precisely the size distribution. ${ }^{14,42}$

\section{Conclusion and Outlook}

The results here are significant in that we have demonstrated a remarkably easy, efficient, and scalable way of creating an effective 1-month LAR for leuprolide and demonstrated the potential for other important peptides for controlled release (e.g., octreotide). Imagine the simple formulation of drug-free microspheres that are terminally sterilized and used to encapsulate peptides by a single aseptic aqueous mixing step. It is reasonable to expect that utilizing this approach could lead to a significantly reduced

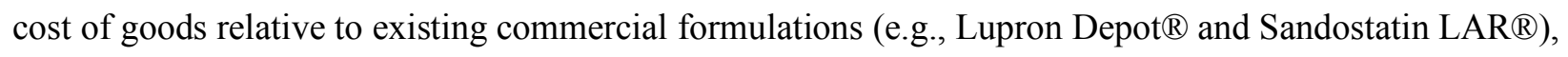
leading to more widespread use of LARs for these and other important peptides. Large scale encapsulation could be tested for a given microsphere batch on a small scale first to ensure the performance. This simple encapsulation paradigm obviates (a) the complex steps necessary to prevent peptide loss during encapsulation by the solvent evaporation method, ${ }^{33,43}$ (b) the use of oil and multiple

organic solvents during the coacervation method, ${ }^{43,44}$ and (c) low yields experienced by spray drying. ${ }^{44,45}$ More work is needed to expand the potential of this encapsulation approach, namely, to determine (a) 
optimal drug-free microsphere formulation, encapsulation and sterilization conditions, (b) how to improve peptide instability in PLGA and related polymers, (c) how to apply the approach to peptides with neutral to negative net charge, and (d) how to incorporate additional functionality to the surface of the polymer before encapsulation. With these initiatives many more commercial peptide LARs can be envisioned in the future.

\section{Materials and Methods}

\section{PLGA Microsphere Formulation}

Drug-free PLGA microspheres were prepared by using a double emulsion solvent evaporation method.

PLGA 75/25 13 kD Mw acid-capped (Wako, Japan), $1 \mathrm{~g}$ was dissolved in $1 \mathrm{~mL}$ methylene chloride. Once dissolved, $100 \mu \mathrm{l}$ of a $500 \mathrm{mg} / \mathrm{mL}$ trehalose in $\mathrm{ddH}_{2} \mathrm{O}$ solution was added to the polymer solution to increase polymer porosity and then homogenized (VirTis Tempest I.Q. ${ }^{2}$ ) for $1 \mathrm{~min}$ at $10,000 \mathrm{rpm}$ to create a water-in-oil (w/o) emulsion. A $5 \%$ poly vinyl alcohol (PVA) solution was added to the emulsion, which was then vortexed (Scientific Industries Vortex Genie 2) for 1 min at maximum speed. The solution was then added to a stirring bath of $0.5 \%$ PVA and stirred for 3 hours to allow for solvent evaporation. After hardening, microspheres were washed with $1 \mathrm{~L} \mathrm{ddH_{2 }}$ O and sieved for size, 20-63 $\mu$ m. Microspheres were lyophilized (Labconco FreeZone 2.5 ) at $<0.1 \mathrm{mBar}$ and stored, desiccated, at $-20^{\circ} \mathrm{C}$ until further use.

\section{Irradiation of Microspheres}

Preformed, drug-free microspheres were weighed out into glass ampules, $\sim 100 \mathrm{mg}$ per ampule, and sealed under vacuum. Sealed ampules were exposed to gamma irradiation at a dose of $1.8 \mathrm{Mrad}$ and dose rate of $0.64 \mathrm{Mrad} / \mathrm{hr}$ using a ${ }^{60} \mathrm{Co}$ source. Radiation treatment was performed by the Oregon State University Radiation Center (Corvallis, OR).

\section{Remote Loading of Microspheres by Peptide Absorption}


Microspheres with or without terminal sterilization were loaded by incubating $90 \mathrm{mg}$ of microspheres in 0.1 M HEPES buffer $\mathrm{pH} 7.4$ with $20 \mathrm{mg} / \mathrm{mL}$ dissolved peptide for $24 \mathrm{~h}$ at $37{ }^{\circ} \mathrm{C}$ with gentle rotational agitation. Loading solution volume was $0.5 \mathrm{~mL}$ or $0.375 \mathrm{~mL}$ for leuprolide giving respective 180 and 240 $\mathrm{mg} / \mathrm{mL}$ initial microsphere concentrations. All other peptides were loaded at $180 \mathrm{mg} / \mathrm{mL}$ microspheres concentration solution under identical conditions. After incubation, microspheres were centrifuged for 5 min at $8,000 \mathrm{rpm}$ and the supernatant removed. Loaded microspheres were washed three times with $1 \mathrm{~mL}$ of $\mathrm{ddH}_{2} \mathrm{O}$. Loaded microspheres were then freeze dried and stored at $-20{ }^{\circ} \mathrm{C}$.

\section{UPLC Analysis of Peptides}

Leuprolide concentration in solution was analyzed by UPLC (Waters, Parsippany, NJ). Prior to analysis solutions were syringe filtered (0.45 um). Samples were run on a C18 (Aquity BEH C18, $0.7 \mu \mathrm{m}, 2.1$ $\mathrm{x} 100 \mathrm{~mm})$ column using a gradient method of $25 \%$ acetonitrile $(\mathrm{ACN})+0.1 \%$ trifluoroacetic acid (TFA): $75 \% \mathrm{ddH}_{2} \mathrm{O}+0.1 \%$ TFA to $35 \% \mathrm{ACN}+\mathrm{TFA}: 65 \% \mathrm{ddH}_{2} \mathrm{O}+$ TFA over 3.5 minutes at a flow rate of $0.5 \mathrm{~mL} / \mathrm{min}$. Leuprolide was detected by UV at $215 \mathrm{~nm}$. The same gradient method was used to analyze octreotide samples at a flow rate of $0.4 \mathrm{ml} / \mathrm{min}$ for 4 minutes. Vasopressin was analyzed using an isocratic method of $20 \% \mathrm{ACN}+\mathrm{TFA}: 80 \% \mathrm{ddH}_{2} \mathrm{O}+\mathrm{TFA}$ at $0.4 \mathrm{ml} / \mathrm{min}$ over 2 minutes. Salmon Calcitonin samples were also run isocratically at $37 \% \mathrm{ACN}+\mathrm{TFA}: 63 \% \mathrm{ddH}_{2} \mathrm{O}+\mathrm{TFA}$ for 1.8 min at 0.5 $\mathrm{ml} / \mathrm{min}$. Exenatide samples were run on a gradient of $25 \% \mathrm{ACN}+\mathrm{TFA}: 75 \% \mathrm{ddH}_{2} \mathrm{O}+\mathrm{TFA}$ to $90 \% \mathrm{ACN}$ + TFA: $10 \% \mathrm{ddH}_{2} \mathrm{O}+$ TFA over 4 minutes at a flow rate of $0.5 \mathrm{~mL} / \mathrm{min}$. All peptides were analyzed on the same column and by UV at $215 \mathrm{~nm}$.

\section{Evaluation of Peptide Loading and Encapsulation Efficiency by Mass Loss}

Mass loss was used to determine leuprolide, vasopressin, salmon calcitonin and octreotide loading. To accomplish this, the supernatant was removed after loading and wash solutions were analyzed by UPLC (Acquity H-Class, Waters) as detailed above. Volume of loading solution, which changes during 
encapsulation with high concentration of suspended microspheres, was determined after encapsulation by centrifuging ( $5 \mathrm{~min}, 4000 \mathrm{rpm}$ ) the particle suspension then removing $200 \mu \mathrm{L}$ of supernatant. Particles were then washed by adding $1 \mathrm{~mL}$ of $\mathrm{diH}_{2} \mathrm{O}$ to the particles then centrifuged again and $900 \mu \mathrm{L}$ of supernatant removed. The wash step was repeated two more time for a total of 3 wash steps. Peptide loading is calculated from the weight ratio of peptide encapsulated to total microsphere weight (w/w \%). Encapsulation efficiency is the ratio of actual peptide loaded to theoretical peptide loading (total peptide in solution/ (total peptide and polymer added)).

\section{Evaluation of Peptide Loading and Encapsulation Efficiency by Nitrogen Analysis}

Total nitrogen analysis was used to determine loading of all peptides (leuprolide, octreotide, exenatide,

protirelin, pramlintide, salmon calcitonin, vasopresin) by using a modified automated Dumas technique. ${ }^{46}$ Briefly, $\sim 2 \mathrm{mg}$ of loaded microspheres were aliquoted into tin pans, in triplicate, then crimped to remove excess air prior to analysis. Samples were run on a Leco TrueSpec ${ }^{\circledR}$ Micro CHN (LECO, USA). The instrument was first blanked without samples or tins to establish atmospheric baselines. Using USP grade EDTA the percent of carbon, hydrogen and nitrogen were verified to be within anticipated range and these values were set as standards. Lyophilized peptide standards were run to verify the percent nitrogen in the peptide and set a peptide factor. Microsphere samples were then dropped into a combustion chamber at $1050{ }^{\circ} \mathrm{C}$, which converts all nitrogen to nitrogen gas, which is then quantified by a thermal conductivity cell. Peptide content was determined by multiplying the nitrogen mass by the peptide factor after first subtracting the nitrogen mass from negative controls (unloaded microspheres).

\section{Evaluation of PLGA Glass Transition Temperature}

The dry and hydrated glass transition temperature ( $T_{\mathrm{g}}$ ) of 75/25 PLGA microspheres was measured by differential scanning calorimetry (DSC) analysis (Discovery DSC, TA Instruments, New Castle, DE). Drug-free irradiated and non-irradiated microspheres (4-6 mg) were weighed and added to non-hermetic 
pans. For hydrated measurements, drug-free irradiated and non-irradiated microspheres (10 -12 mg) were weighed and suspended in $200 \mu \mathrm{l}$ of $0.1 \mathrm{M}$ HEPES solution $(\mathrm{pH} 7.4)$ at $37^{\circ} \mathrm{C}$ for $24 \mathrm{~h}$ on a rotator. After incubation, microspheres were centrifuged, and the supernatant removed to create a slurry. Both dry and hydrated samples underwent a heat/cool/heat cycle $5{ }^{\circ} \mathrm{C}$ to $90{ }^{\circ} \mathrm{C}$, at $1{ }^{\circ} \mathrm{C} /$ minute. $\mathrm{DSC}$ results from the second heat cycle were used for analysis.

\section{Evaluation of In Vitro Release of Peptide-loaded Microspheres}

Leuprolide release from irradiated and non-irradiated microspheres loaded at $180 \mathrm{mg} / \mathrm{mL}$ and $240 \mathrm{mg} / \mathrm{mL}$ peptide solution concentration was measured in vitro by determining the percent remaining in microspheres, as was done by Takada. ${ }^{47}$ Briefly, $10 \mathrm{mg}$ of loaded microspheres were weighted out, in duplicate, for each time point to be tested (Day 1, 3, 5, 7, 14, 21, 28), 14 samples total, and incubated with $1 \mathrm{~mL}$ of phosphate buffered saline $+0.02 \%$ Tween 80 (PBST) with mild agitation at $37{ }^{\circ} \mathrm{C}$. At each time point all samples were centrifuged for $5 \mathrm{~min}$ at $8,000 \mathrm{rpm}$ and $900 \mu 1$ of the release buffer was removed to ensure that no particles were collected. Samples for Day 1 were then stopped and dried for 24- $48 \mathrm{~h}$ at 25 ${ }^{\circ} \mathrm{C}$. For all remaining samples, for days $3-28,900 \mu 1$ of the removed release media was replaced with fresh PBST and were incubated until the next time point. This process was repeated at each time point. Once samples were stopped and dried on their specific sampling day approximately $5 \mathrm{mg}$ of microspheres were weighed out into an Eppendorf tube for analysis of percent peptide remaining by two-phase extraction as described in Evaluation of Peptide Remaining by Two-phase Extraction below. For all other peptides the parent peptide peak in the release media was quantified by UPLC analysis as described above.

\section{Evaluation of Peptide Remaining by Two-phase Extraction}

Extraction of peptide in microspheres was used to determine the amount of peptide remaining after incubation for leuprolide release as well as both leuprolide and octreotide encapsulation during loading. Briefly, $\sim 5 \mathrm{mg}$ of loaded microspheres were dissolved in $1 \mathrm{~mL}$ methylene chloride and $2 \mathrm{~mL}$ of $1 \mathrm{M}$ 
sodium acetate $(\mathrm{pH} 4)$ was added. The two-phase mixture was vortexed for 1 minute then centrifuged for 4 min at 4,000 rpm and $1.5 \mathrm{~mL}$ of the upper aqueous phase was removed. The removed $1.5 \mathrm{~mL}$ was replaced with a fresh $1.5 \mathrm{~mL}$ of sodium acetate and the process repeated 4 more times for a total of 5 extractions. After the 5th extraction, $1.5 \mathrm{~mL}$ of $1 \mathrm{M}$ sodium acetate $+1 \mathrm{M}$ sodium chloride $(\mathrm{pH} 4)$ was added. This process of vortexing then centrifugation was repeated 6 times resulting in 11 total extractions, which were analyzed by UPLC. ${ }^{13}$

\section{Evaluation of Efficacy of Leuprolide-loaded Microspheres in Rats}

The efficacy of leuprolide loaded microspheres for testosterone suppression was tested in male SpragueDawley rats (7 weeks old) and compared to commercial 1-month Lupron Depot ${ }^{\circledR}$. Both non-irradiated and irradiated microspheres were injected into rats at a dose of $100 \mu \mathrm{g} / \mathrm{kg} /$ day based on drug loading by mass loss from solution. Microspheres were suspended in an injection vehicle of $0.5 \%$ low viscosity carboxy methyl cellulose (CMC), $0.1 \% \mathrm{w} / \mathrm{v}$ Tween 80 and $5 \%$ D-mannitol and were administered subcutaneously. Lupron Depot ${ }^{\circledR}$ was reconstituted and administered according to the package insert. ${ }^{48}$ Blood was sampled from the jugular vein on days 1,3, 7 and weekly thereafter to determine plasma testosterone levels. Whole blood samples were centrifuged for 10 minutes at $4000 \mathrm{rpm}$ (Eppendorf 5810R) to separate the plasma. The plasma was then removed and stored at $-80{ }^{\circ} \mathrm{C}$ until analysis. Plasma testosterone samples were analyzed, in duplicate, by RIA analysis at the University of Pennsylvania (RIA Biomarkers Core, Penn Diabetes Center).

\section{Evaluation of Pharmacokinetics of Peptide-loaded Microspheres in Rats}

The pharmacokinetics studies of peptide-loaded microspheres were performed in male Sprague-Dawley rats. Sandostatin LAR ${ }^{\circledR}$ and peptide-loaded microspheres were subcutaneously injected into the back of rats $(\mathrm{n}=4,18 \mathrm{mg} / \mathrm{kg}$ for octreotide and bremelanotide, and $4 \mathrm{mg} / \mathrm{kg}$ for salmon calcitonin). Blood samples were drawn from the jugular vein at predetermined time points (Day 1, 3, 7, 14, 21, 28, 35, 42, 49, 56).

Giles et al. 
The blood samples were centrifuged at $4,000 \mathrm{rpm}$ for $10 \mathrm{~min}$, and the plasma was stored at $-80^{\circ} \mathrm{C}$ until analysis.

The quantification of octreotide and bremelanotide in rat plasma was performed by UPLC-MS analysis. Briefly, $100 \mu \mathrm{L}$ of plasma was mixed with $10 \mu \mathrm{L}$ of internal standard $(100 \mathrm{ng} / \mathrm{mL}$ of leuprolide in $25 \%$ acetonitrile) and $10 \mu \mathrm{L}$ of acetic acid, and was vortexed for $1 \mathrm{~min} .300 \mu \mathrm{L}$ of acetonitrile (containing $0.1 \%$ formic acid) was then added and the mixture was vortexed for another 1 min for protein precipitation. The samples were centrifuged at $12,000 \mathrm{rpm}$ for $10 \mathrm{~min}$, and the supernatant was transferred to a clean tube followed by evaporation under nitrogen flow. The residue was reconstituted in $100 \mu \mathrm{L}$ of $25 \%$ acetonitrile containing $0.1 \%$ formic acid, centrifuged at $12,000 \mathrm{rpm}$ for $10 \mathrm{~min}$, and the supernatant was injected into the LC-MS system. The standard curve was prepared by adding octreotide or bremelanotide solution (dissolved in $25 \%$ acetonitrile) into $100 \mu \mathrm{L}$ of blank rat plasma, and the standard

curve samples were processed using the same method as above for testing samples. All the samples were analyzed by LC-MS (Shimadzu HPLC system and AB Sciex QTrap 5500 mass spectrometer) using a Waters Xbridge ${ }^{\circledR}$ C18 column $(2.1 \times 50 \mathrm{~mm}, 3.5 \mu \mathrm{m})$. The mobile phase consisted of water containing $0.1 \%$ formic acid (A) and acetonitrile containing $0.1 \%$ formic acid (B), and the flow rate was $0.4 \mathrm{~mL} / \mathrm{min}$. The gradient elution started from $15 \% \mathrm{~B}$, changed to $40 \% \mathrm{~B}$ within $1.8 \mathrm{~min}$ and held for $0.7 \mathrm{~min}$, then changed to $95 \% \mathrm{~B}$ within $0.1 \mathrm{~min}$ and held for $0.9 \mathrm{~min}$, finally returning to $15 \% \mathrm{~B}$ within $0.1 \mathrm{~min}$ and maintained for $1.9 \mathrm{~min}$ for equilibration.

The concentration of salmon calcitonin in rat plasma was determined using an ELISA kit (Salmon Calcitonin ELISA Kit, abx150375, Abbexa). The assay was performed by the Cancer Center Immunology Core at the University of Michigan following the ELISA kit manual.

The PK parameters were calculated with Matlab using a non-compartmental model.

\section{Acid End-group Content of PLGA}

Acid number was determined similarly as described by Mehta et al. ${ }^{49}$ Briefly, $150 \mathrm{mg}$ of 75/25 PLGA microspheres were dissolved in $20 \mathrm{~mL}$ of a 1:1 tetrahydrofuran:acetone (THF: acetone) mixture. 
Approximately 7 drops of $0.5 \mathrm{wt} \%$ phenolphthalein was added to the solution of dissolved microspheres. The solution was then titrated with $0.01 \mathrm{M}$ methanolic potassium (methanolic $\mathrm{KOH}$ ) until the solution was observed to maintain a slight pink color through the solution. The acid end-group content was then calculated as $(($ volume of titrant $) *(0.01 \mathrm{M} \mathrm{KOH}) *(\mathrm{KOH}$ molecular weight $) /$ (mass of PLGA microspheres).

\section{Isothermal Titration Calorimetry of Peptide-PLGA Interactions}

Peptide salts were dissolved in dimethylsulfoxide (DMSO) to prepare a final peptide solution of 7.88 mM. PLGA 75/25 polymer was dissolved in DMSO for a $1.68 \mathrm{mM}$ polymer solution based on the acid number of PLGA $(0.261 \pm 0.004 \mathrm{mmol} / \mathrm{g}$ PLGA, $\mathrm{n}=3)$, as previously described. ${ }^{50}$ Prepared peptide and polymer solutions and DMSO were degassed 10 min prior to NanoITC (TA Instruments, New Castle, DE) calorimetry studies to eliminate air bubbles. Degassed DMSO was added to the reference cell (300 $\mu \mathrm{l})$ and the polymer solution $(300 \mu \mathrm{l})$ was added to the sample cell. The ITC syringe was filled with $50 \mu \mathrm{l}$ of the degassed peptide solution. The polymer solution was titrated with 15 injections of $2.5 \mu$ peptide solution/injection with an injection interval of $300 \mathrm{~s}$ and constant stirring of $350 \mathrm{rpm}$. Heat produced by peptide dilution was evaluated by a control experiment, titrating peptide solution into DMSO under the same experimental conditions. The interaction heat for each injection was calculated by correcting the heats from the peptide dilution. The resulting corrected injection heats were plotted as a function of the molar ratio of peptides to the acid number of PLGA, fitted with a model for one-site independent model and analyzed with a nonlinear least-squares minimization algorithm by using the NanoAnalysis software, version 3.7.5 (TA Instruments, New Castle, DE). From the data fit the molar enthalpy change, reaction stoichiometry and peptide dissociation constant were obtained. From model fits, the molar entropy and Gibbs free energy changes and peptide association constant were also calculated. ${ }^{51}$

\section{Statistical Analysis}


All of the results presented in this study are mean \pm S.E.M. Statistical comparison of the area under the plasma concentration-time curve of SLAR and remote-loaded octreotide was performed by unpaired Ttest assuming $\mathrm{p}<0.05$ for statistical significance.

\section{Data Availability}

The authors declare that all data supporting the results in this study are available within the paper and its Supplementary Information.

\section{References}

1 Bak, A. et al. Physicochemical and Formulation Developability Assessment for Therapeutic Peptide Delivery-A Primer. The AAPS Journal 17, 144-155, doi:10.1208/s12248-014-9688-2 (2015).

2 Bruno, B. J., Miller, G. D. \& Lim, C. S. Basics and recent advances in peptide and protein drug delivery. Ther Deliv 4, 1443-1467, doi:10.4155/tde.13.104 (2013).

3 Zhang, L. \& Schwendeman, S. in Peptides for Youth Vol. 611 Advances in Experimental Medicine and Biology (eds SusanDel Valle, Emanuel Escher, \& WilliamD Lubell) Ch. 264, 611-613 (Springer New York, 2009).

4 Stevenson, C. L., Rhodes, C. A. \& Prestrelski, S. J. in Long Acting Injections and Implants (eds Jeremy C. Wright \& Diane J. Burgess) 409-427 (Springer US, 2012).

5 Hoffman, A. S. The origins and evolution of "controlled" drug delivery systems. $J$ Control Release 132, 153-163, doi:10.1016/j.jconrel.2008.08.012 (2008).

6 Wright, J. C. \& Hoffman, A. S. in Long Acting Injections and Implants (eds C. Jeremy Wright \& J. Diane Burgess) 11-24 (Springer US, 2012).

7 Schwendeman, S. P. Recent Advances in the Stabilization of Proteins Encapsulated in Injectable PLGA Delivery Systems. 19, 26, doi:10.1615/CritRevTherDrugCarrierSyst.v19.i1.20 (2002).

8 Zhu, G., Mallery, S. R. \& Schwendeman, S. P. Stabilization of proteins encapsulated in injectable poly (lactide- co-glycolide). Nat Biotech 18, 52-57 (2000).

9 van de Weert, M., Hennink, W. E. \& Jiskoot, W. Protein instability in poly(lactic-coglycolic acid) microparticles. Pharmaceutical research 17, 1159-1167 (2000).

10 Hines, D. J. \& Kaplan, D. L. Poly (lactic-co-glycolic acid) controlled release systems: experimental and modeling insights. Critical reviews in therapeutic drug carrier systems 30, 257-276 (2013).

11 Fu, Y. \& Kao, W. J. Drug release kinetics and transport mechanisms of non-degradable and degradable polymeric delivery systems. Expert opinion on drug delivery 7, 429-444, doi:10.1517/17425241003602259 (2010). 
12 Schwendeman, S. P., Shah, R. B., Bailey, B. A. \& Schwendeman, A. S. Injectable controlled release depots for large molecules. J Control Release 190c, 240-253, doi:10.1016/j.jconrel.2014.05.057 (2014).

13 Sophocleous, A. M. et al. The nature of peptide interactions with acid end-group PLGAs and facile aqueous-based microencapsulation of therapeutic peptides. J Control Release 172, 662-670, doi:http://dx.doi.org/10.1016/j.jconrel.2013.08.295 (2013).

14 Reinhold, S. E., Desai, K.-G. H., Zhang, L., Olsen, K. F. \& Schwendeman, S. P. SelfHealing Microencapsulation of Biomacromolecules without Organic Solvents.

Angewandte Chemie International Edition 51, 10800-10803, doi:10.1002/anie.201206387 (2012).

15 Na, D. H. \& DeLuca, P. P. PEGylation of Octreotide: I. Separation of Positional Isomers and Stability Against Acylation by Poly(D,L-lactide-co-glycolide). Pharmaceutical research 22, 736-742, doi:10.1007/s11095-005-2589-4 (2005).

16 Barenholz, Y. Doxil® — The first FDA-approved nano-drug: Lessons learned. J Control Release 160, 117-134, doi:https://doi.org/10.1016/j.jconrel.2012.03.020 (2012).

17 Cardarelli, F. et al. The intracellular trafficking mechanism of Lipofectamine-based transfection reagents and its implication for gene delivery. Scientific Reports 6, 25879, doi:10.1038/srep25879

https://www.nature.com/articles/srep25879\#supplementary-information (2016).

18 Holmen, S. L. et al. Efficient lipid-mediated transfection of DNA into primary rat hepatocytes. 31, 347-351, doi:10.1007/bf02634283 (1995).

19 Beig, A., Feng, L., Walker, J., Ackermann, R., Wang, J. H.Y., Jiang, X., Schwendeman, S. P. in AAPS PharmSci 360 (Washington DC, 2018).

20 Karantanos, T., Corn, P. G. \& Thompson, T. C. Prostate cancer progression after androgen deprivation therapy: mechanisms of castrate resistance and novel therapeutic approaches. Oncogene 32, 5501-5511, doi:10.1038/onc.2013.206 (2013).

21 Shi, Y. et al. Fc-modified exenatide-loaded nanoparticles for oral delivery to improve hypoglycemic effects in mice. Scientific Reports 8, 726, doi:10.1038/s41598-018-19170y (2018).

22 Dill, K. A., Truskett, T. M., Vlachy, V. \& Hribar-Lee, B. Modeling Water, the Hydrophobic Effect, and Ion Solvation. Annual Review of Biophysics and Biomolecular Structure 34, 173-199, doi:10.1146/annurev.biophys.34.040204.144517 (2005).

23 Pierce, M. M., Raman, C. S. \& Nall, B. T. Isothermal Titration Calorimetry of ProteinProtein Interactions. Methods 19, 213-221, doi:http://dx.doi.org/10.1006/meth.1999.0852 (1999).

24 Leung, D. H., Bergman, R. G. \& Raymond, K. N. Enthalpy-Entropy Compensation Reveals Solvent Reorganization as a Driving Force for Supramolecular Encapsulation in Water. Journal of the American Chemical Society 130, 2798-2805, doi:10.1021/ja075975z (2008).

25 Cort, J. R. et al. Solution state structures of human pancreatic amylin and pramlintide. Protein Engineering, Design and Selection 22, 497-513, doi:10.1093/protein/gzp029 (2009).

26 Li, T. et al. Characterization of Attributes and in vitro Performance of Exenatide-loaded PLGA Long-acting Release Microspheres. European Journal of Pharmaceutics and Biopharmaceutics, doi:https://doi.org/10.1016/j.ejpb.2020.10.008 (2020). 
27 Zhang, Y. \& Schwendeman, S. P. Minimizing acylation of peptides in PLGA microspheres. Journal of Controlled Release 162, 119-126, doi:http://dx.doi.org/10.1016/j.jconrel.2012.04.022 (2012).

28 Sandostatin LAR(R) [Package Insert].

29 Dhillon, S. \& Keam, S. J. Bremelanotide: First Approval. Drugs 79, 1599-1606, doi:10.1007/s40265-019-01187-w (2019).

30 Beig, A. et al. Physical-Chemical Characterization of Octreotide Encapsulated in Commercial Glucose-Star PLGA Microspheres. Molecular Pharmaceutics, doi:10.1021/acs.molpharmaceut.0c00619 (2020).

31 Huskey, S.-E. W., Reynolds, David J., Kramer, Michael S., Shadiack, Annette M., Leung, Edward Y.S. ABSTRACTS. Drug Metabolism Reviews 38, 1-258, doi:10.1080/03602530600914867 (2006).

32 Tang, Y. \& Singh, J. Thermosensitive drug delivery system of salmon calcitonin: in vitro release, in vivo absorption, bioactivity and therapeutic efficacies. Pharmaceutical research 27, 272-284, doi:10.1007/s11095-009-0015-z (2010).

33 Varde, N. K. \& Pack, D. W. Microspheres for controlled release drug delivery. Expert Opinion on Biological Therapy 4, 35-51, doi:10.1517/14712598.4.1.35 (2004).

34 Kim, K. K. \& Pack, D. W. in BioMEMS and Biomedical Nanotechnology: Volume I Biological and Biomedical Nanotechnology (eds Mauro Ferrari, Abraham P. Lee, \& L. James Lee) 19-50 (Springer US, 2006).

35 Brown, L. R. Commercial challenges of protein drug delivery. Expert Opin Drug Deliv 2, 29-42, doi:10.1517/17425247.2.1.29(2005).

36 Jordan, F. et al. Sustained release hGH microsphere formulation produced by a novel supercritical fluid technology: In vivo studies. J Control Release 141, 153-160, doi:https://doi.org/10.1016/j.jconrel.2009.09.013 (2010).

37 Tracy, M. A. Development and scale-up of a microsphere protein delivery system. Biotechnol Prog 14, 108-115, doi:10.1021/bp9701271 (1998).

38 Schwendeman, S. P., Reinhold, S. E. \& Kang, J. Methods for encapsulation of biomacromolecules in polymers. US 8,017,155 (2011).

39 Desai, K.-G. H. \& Schwendeman, S. P. Active self-healing encapsulation of vaccine antigens in PLGA microspheres. Journal of Controlled Release 165, 62-74, doi:http://dx.doi.org/10.1016/j.jconrel.2012.10.012 (2013).

40 Hutchinson, F. G. Continuous release pharmaceutical compositions. 5,366,734 (1988).

41 Okada, H., Heya, T., Ogawa, Y. \& Shimamoto, T. One-month release injectable microcapsules of a luteinizing hormone-releasing hormone agonist (leuprolide acetate) for treating experimental endometriosis in rats. J Pharmacol Exp Ther 244, 744-750 (1988).

42 Hirota, K. et al. Characterizing release mechanisms of leuprolide acetate-loaded PLGA microspheres for IVIVC development I: In vitro evaluation. J Control Release 244, 302313, doi:10.1016/j.jconrel.2016.08.023 (2016).

43 Freitas, S., Merkle, H. P. \& Gander, B. Microencapsulation by solvent extraction/evaporation: reviewing the state of the art of microsphere preparation process technology. J Control Release 102, 313-332, doi:https://doi.org/10.1016/j.jconrel.2004.10.015 (2005). 
44 Prajapati, V. D., Jani, G. K. \& Kapadia, J. R. Current knowledge on biodegradable microspheres in drug delivery. Expert Opinion on Drug Delivery 12, 1283-1299, doi:10.1517/17425247.2015.1015985 (2015).

45 Mundargi, R. C., Babu, V. R., Rangaswamy, V., Patel, P. \& Aminabhavi, T. M. Nano/micro technologies for delivering macromolecular therapeutics using poly(d,1lactide-co-glycolide) and its derivatives. Journal of Controlled Release 125, 193-209, doi:http://dx.doi.org/10.1016/j.jconrel.2007.09.013 (2008).

46 Etheridge, R. D., Pesti, G. M. \& Foster, E. H. A comparison of nitrogen values obtained utilizing the Kjeldahl nitrogen and Dumas combustion methodologies (Leco CNS 2000) on samples typical of an animal nutrition analytical laboratory. Animal Feed Science and Technology 73, 21-28, doi:http://dx.doi.org/10.1016/S0377-8401(98)00136-9 (1998).

47 Ogawa, Y., Yamamoto, M., Takada, S., Okada, H. \& Shimamoto, T. Controlled-release of leuprolide acetate from polylactic acid or copoly(lactic/glycolic) acid microcapsules: influence of molecular weight and copolymer ratio of polymer. Chem Pharm Bull (Tokyo) 36, 1502-1507 (1988).

48 Lupron Depot(R) [Package insert], 2012).

49 Mehta, R. C., Thanoo, B. C. \& Deluca, P. P. Peptide containing microspheres from low molecular weight and hydrophilic poly(d,1-lactide-co-glycolide). J Control Release 41, 249-257, doi:http://dx.doi.org/10.1016/0168-3659(96)01332-6 (1996).

50 Hong, J. K. Y. \& Schwendeman, S. P. Characterization of Octreotide-PLGA Binding by Isothermal Titration Calorimetry. Biomacromolecules 21, 4087-4093, doi:10.1021/acs.biomac.0c00885 (2020).

51 Brown, A. Analysis of Cooperativity by Isothermal Titration Calorimetry. International Journal of Molecular Sciences 10, 3457 (2009).

52 Göpferich, A. Mechanisms of polymer degradation and erosion. Biomaterials 17, 103 114, doi:http://dx.doi.org/10.1016/0142-9612(96)85755-3 (1996).

53 Davidson, J. A. Mercury porosimetry studies II. The application of mercury porosimetry to porous polymer powders. Powder Technology 23, 239-244, doi:http://dx.doi.org/10.1016/0032-5910(79)87013-8 (1979).

54 Hansen, L. D., Fellingham, G. W. \& Russell, D. J. Simultaneous determination of equilibrium constants and enthalpy changes by titration calorimetry: Methods, instruments, and uncertainties. Analytical biochemistry 409, 220-229, doi:https://doi.org/10.1016/j.ab.2010.11.002 (2011).

\section{Author Contributions}

M.B.G., A.S. and S.P.S. designed the project. M.B.G., J.K.Y.H. and S.P.S. wrote the manuscript. M.B.G., J.K.Y.H., Y.L. and J.T. performed the experiments with contributions from A.B, and T.L. M.B.G., J.K.Y.H., A.S. and S.P.S. analyzed and interpreted the data. 


\section{Competing Interests}

S.P.S., A.S. and M.B.G. are inventors of patents on the technology described in this work, which are assigned to the University of Michigan.

Correspondence and request for materials should be addressed to S.P.S. 


\section{Supplemental Material}

Remote loading allows for microsphere formulation and optimization prior to loading. Very few pores were visible on the surface (Supplementary Figure 1) of preformed drug-free microspheres despite the presence of a porosigen (trehalose) in the formulation. Microspheres prepared in this way tend to have significant porosity, as measured by mercury intrusion ${ }^{14,52,53}$ to facilitate rapid peptide encapsulation and release. Gamma irradiation did not significantly affect the surface morphology of the microspheres

(Supplementary Figure 1). However, microspheres lost their smooth surface after peptide loading

(Supplementary Figure 1) as the peptide forms the salt with the PLGA carboxylic acid end groups.
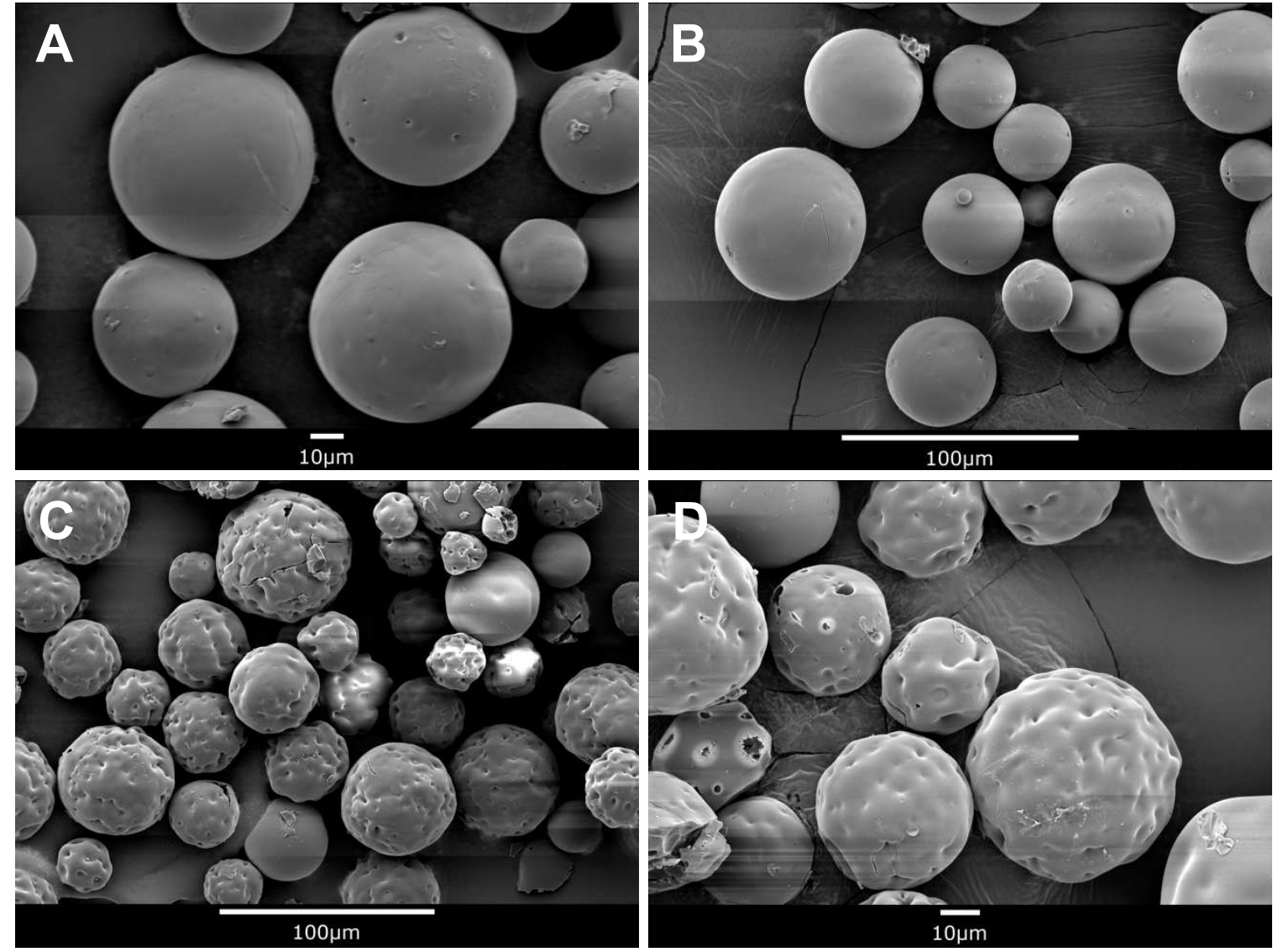

Supplementary Figure 1. SEM of (a) PLGA microspheres prior to gamma irradiation, (b) after gamma irradiation, (c) nonirradiated leuprolide-loaded PLGA microspheres loaded at $180 \mathrm{mg} / \mathrm{mL}$, and (d) non-irradiated leuprolide-loaded PLGA microspheres loaded at $240 \mathrm{mg} / \mathrm{mL}$.

The level of burst release is important for leuprolide as there is a downregulation of the gonadotropin receptor, as evidenced by the initial increase in testosterone in Fig 3 and Supplementary Fig 5 (see 
below). During in vitro studies Lupron Depot ${ }^{\circledR}$ microspheres exhibited an initial burst of $22.3 \pm 0.4 \%$ release on 1 day. We compared the initial burst release of leuprolide from irradiated and non-irradiated microspheres at both peptide loading concentrations $(180 \mathrm{mg} / \mathrm{mL}$ and $240 \mathrm{mg} / \mathrm{mL})$. We see that microspheres loaded at the higher concentration had a lower initial burst independent of gamma irradiation exposure and all formulations had an initial burst within error of that seen for the Lupron $\operatorname{Depot}{ }^{\circledR}($ Supplementary Fig 2).

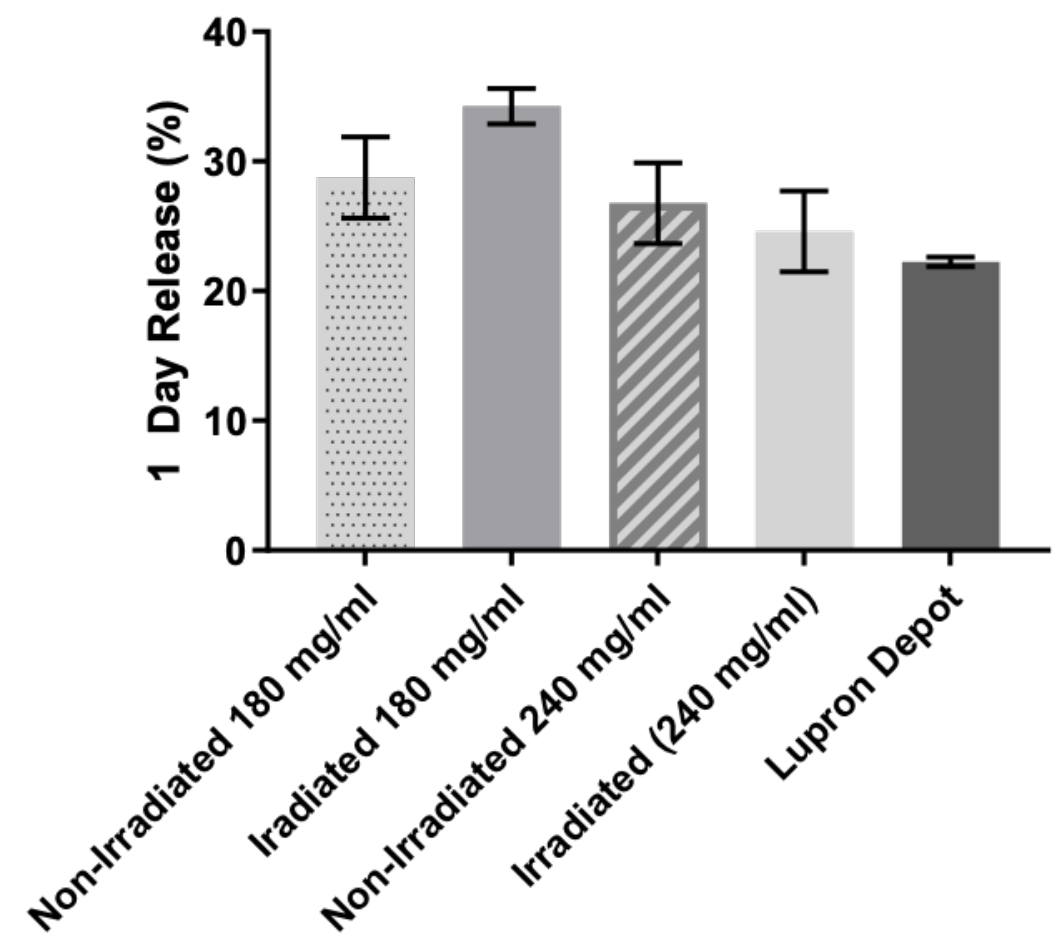

Supplementary Figure 2. Initial burst release of leuprolide from irradiated and non-irradiated microspheres loaded at 180 $\mathrm{mg} / \mathrm{mL}$ and $240 \mathrm{mg} / \mathrm{mL}$ leuprolide acetate in 0.5M HEPES buffer solution pH 7.4 compared to Lupron Depot ${ }^{\circledR}$. Mean \pm SEM $(n=2)$.

Looking closer at the in vitro release of leuprolide from microspheres loaded at $240 \mathrm{mg} / \mathrm{mL}$ with and without gamma irradiation we see that the two formulations exhibit a similar release profile with regard to release rate and total peptide release over 1 month (Supplementary Fig 3). Irradiated and non-irradiated 
microspheres released roughly $80 \%$ leuprolide, which is similar to that seen for Lupron Depot® in vitro release.

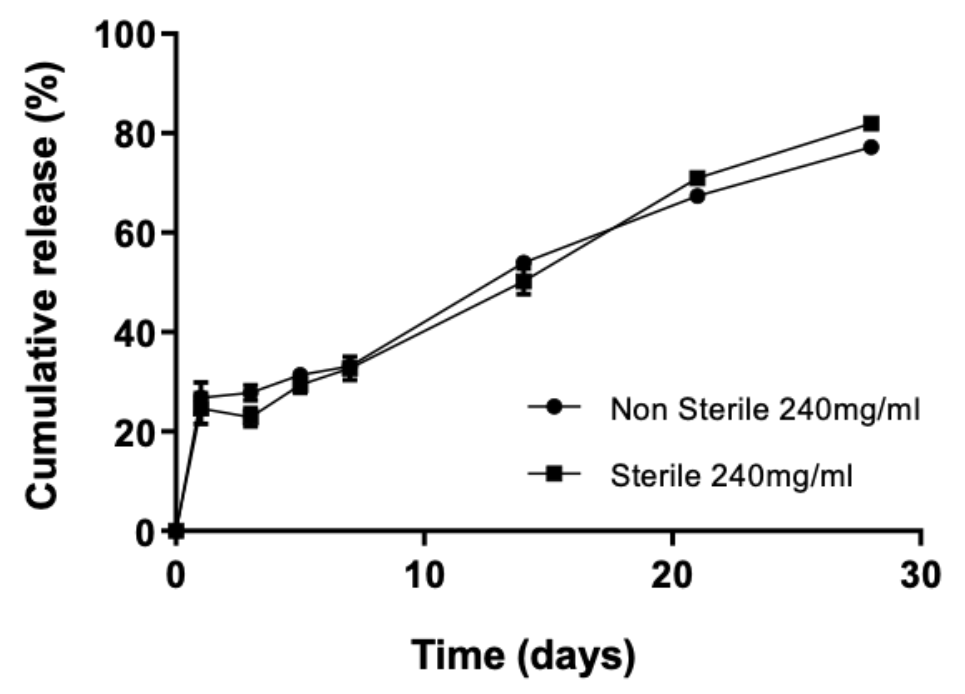

Supplementary Figure 3. Cumulative in vitro leuprolide release from remote-loaded PLGA microspheres with and without prior sterilization by gamma irradiation of the blank PLGA microspheres. Peptide loading concentration was $240 \mathrm{mg} / \mathrm{ml}$.

The general applicability of remote loading to additional peptides (exenatide, protirelin, pramlintide) was tested under the same loading conditions and at $180 \mathrm{mg} / \mathrm{mL}$ microsphere concentration as leuprolide. The titration of exenatide to PLGA (Supplementary Fig 4) exhibited a step function, which is possibly due to the large c-window (i.e. the optimal range of experimental data values needed to maximize fit parameter confidence) at the current working condition. ${ }^{54}$ Although the data have allowed us to estimate the binding enthalpy and the stoichiometry of the interaction between exenatide and PLGA, further work will be needed to optimize the c-window in order to obtain an accurate binding affinity estimation. Remote loading of exenatide resulted in $23.1 \pm 1.7 \%$ encapsulation efficiency, with $2.3 \pm 0.2 \%$ loading (Supplementary Table 1). It is noteworthy that exenatide ( $\mathrm{pI}=4.38)$ was the only net negatively charged peptide at the remote loading condition ( $\mathrm{pH} 7.4)$ among the tested peptides. Hence, it is logical to expect the repulsion between the negatively charged exenatide and the anionic polymer end groups limited binding, causing the relatively low loading and encapsulation efficiency of exenatide described above. 
Similar to exenatide, protirelin also showed low encapsulation efficiency and loading in 75/25 PLGA microspheres by the remote loading process. For all peptides the loading was measured by several methods and the loading values obtained being fairly consistent regardless of quantification method used (Supplementary Table 1).

Supplementary Table 1. Quantification of peptide loading by mass loss, extraction or nitrogen analysis

\begin{tabular}{|c|c|c|c|c|c|}
\hline Peptide & Sterilized & $\begin{array}{c}\text { Microsphere } \\
\text { concentration } \\
(\mathrm{mg} / \mathrm{mL})\end{array}$ & By mass loss (\%) & By extraction (\%) & By nitrogen analysis (\%) \\
\hline \multirow[t]{4}{*}{ Leuprolide } & No & 180 & $9.65 \pm 0.01$ & $9.37 \pm 0.03$ & $\mathrm{~N} / \mathrm{A}$ \\
\hline & Yes & 180 & $9.48 \pm 0.01$ & $8.93 \pm 0.13$ & $\mathrm{~N} / \mathrm{A}$ \\
\hline & No & 240 & $7.43 \pm 0.01$ & $7.57 \pm 0.05$ & $\mathrm{~N} / \mathrm{A}$ \\
\hline & Yes & 240 & $7.25 \pm 0.01$ & $6.63 \pm 0.10$ & $\mathrm{~N} / \mathrm{A}$ \\
\hline Octreotide & No & 180 & $8.49 \pm 0.01$ & $6.67 \pm 0.10$ & $6.87 \pm 0.02$ \\
\hline Vasopressin & No & 180 & $8.00 \pm 0.32$ & NA & $8.49 \pm 0.15$ \\
\hline $\begin{array}{l}\text { Salmon } \\
\text { Calcitonin }\end{array}$ & No & 180 & $8.17 \pm 0.66$ & NA & $10.9 \pm 0.22$ \\
\hline Exenatide & No & 180 & $2.11 \pm 0.47$ & NA & $2.30 \pm 0.20$ \\
\hline Protirelin & No & 180 & $2.77 \pm 0.07$ & NA & $2.77 \pm 0.07$ \\
\hline Pramlintide & No & 180 & NA & NA & $9.77 \pm 0.13$ \\
\hline Bremelanotide & No & 180 & NA & $8.37 \pm 0.07$ & $7.77 \pm 0.11$ \\
\hline
\end{tabular}

Isothermal titration calorimetry results for protirelin supported the loading results as it did not exhibit significant evidence of binding, possibly due to its small size and lack of positively charged amino acid residues. The ionic state of the three amino acids-long protirelin relied solely on the ionization of the histidine residue with a $\mathrm{pKa}$ that is quite close to the $\mathrm{pH}$ of the remote loading condition. This weakly positive charge resulted in lack of charge-mediated interaction with the polymer end group. It is unknown why the registered heat of interaction of protirelin and polymer observed in the ITC study was endothermic, but it is important to note that the interaction between peptide and the polymer in DMSO is not the same as the aqueous remote loading environment. Pramlintide has a steep initial curve for heats produced from peptide interaction with the polymer. This results in a high association constant $(\mathrm{Ka}=$ $\left.0.346 \mu \mathrm{M}^{-1}\right)$ and low dissociation constant $(\mathrm{Kd}=2.89 \mu \mathrm{M})$. Pramlintide also had a stoichiometry of almost 1.0 indicating that there is almost complete saturation of available acid terminations with peptide (Supplementary Fig 4). The significant amount of heat released was strong evidence of binding between 
pramlintide and polymer end groups. Pramlintide was positively charged at the remote loading condition so it is reasonable to expect there were charge-mediated interactions between the peptide and the anionic polymer end group. The presence of this interaction is further supported by the high loading and encapsulation efficiency, $9.77 \pm 0.13 \%$ and $97.8 \pm 1.3 \%$ respectively (Supplementary Fig 4).
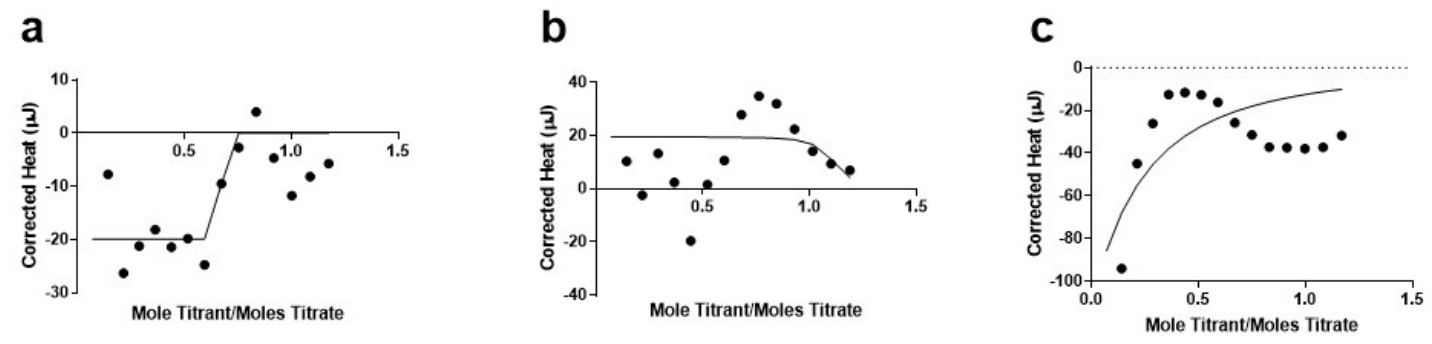

Supplementary Figure 4. ITC thermograms of the binding affinity of exenatide (A), protirelin (B), and pramlintide (C) to 75/25 PLGA-COOH in DMSO. Data shown as heat released per molar ratio of peptide to-COOH PLGA end group.

Octreotide, salmon calcitonin and bremelanotide all showed slow release during in vitro studies. In order to understand potential reasons for this slower release their stability in phosphate buffer at refrigerated (4 $\left.{ }^{\circ} \mathrm{C}\right)$ and in vitro release conditions $\left(37^{\circ} \mathrm{C}\right)$ for 1 or 2 weeks were tested. In 1 week at $37^{\circ} \mathrm{C}$ octreotide was most stable followed by bremelanotide then salmon calcitonin with $\sim 95 \%$ peptide loss. After 2 weeks at $37^{\circ} \mathrm{C}$ salmon calcitonin was not detectable in phosphate buffer (Supplementary Table 2). These stability results, particularly for salmon calcitonin, can partially explain the slower release as peptide could potentially be degrading in phosphate buffer once released as sampling was only done weekly. With more frequent sampling of release media it is possible a higher concentration of peptide would be measured.

Supplementary Table 2. Peptide stability in phosphate buffer. Mean $\pm \operatorname{SEM}(n=3)$.

\begin{tabular}{cccc}
\hline Stability condition/ timepoint & Octreotide $(\boldsymbol{\mu g} / \mathrm{ml})$ & $\begin{array}{c}\text { Bremelanotide } \\
(\boldsymbol{\mu g} / \mathbf{m l})\end{array}$ & Salmon Calcitonin $(\boldsymbol{\mu g} / \mathbf{m l})$ \\
\hline Day 0 & $59.4 \pm 0.04$ & $62.91 \pm 0.16$ & $61.98 \pm 0.34$ \\
$\mathbf{4}^{\circ} \mathrm{C} /$ Day $\mathbf{7}$ & $59.6 \pm 0.11$ & $57.67 \pm 0.01$ & $61.4 \pm 0.24$ \\
$\mathbf{3 7}{ }^{\circ} \mathrm{C} /$ Day $\mathbf{7}$ & $55.55 \pm 0.16$ & $53.53 \pm 0.03$ & $2.97 \pm 0.03$ \\
$\mathbf{3 7}{ }^{\circ} \mathrm{C} /$ Day $\mathbf{1 4}$ & $49.63 \pm 0.56$ & $50.77 \pm 0.25$ & Not Detected
\end{tabular}


In vivo rat studies with control microspheres (without gamma irradiation exposure) loaded at $180 \mathrm{mg} / \mathrm{mL}$ and $240 \mathrm{mg} / \mathrm{mL}$ leuprolide concentration resulted in castration levels within one-week post administration (Supplementary Fig 5) as was seen with irradiated microspheres and Lupron Depot (Figure 3). These results support the reproducibility of the simple remote loading method to provide sustain peptide release in vivo.

a

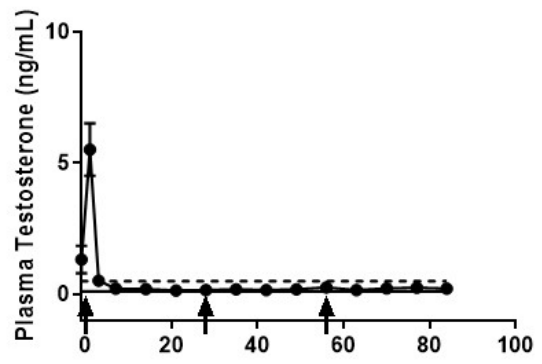

Time (Days) b

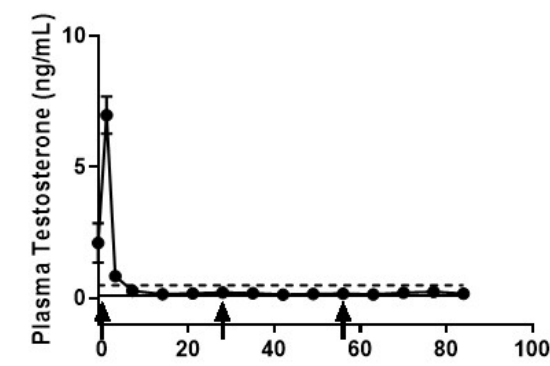

Time (Days)

Supplementary Figure 5. In vivo plasma testosterone levels of male Sprague-Dawley rats administered 3 monthly doses of 180 $\mathrm{mg} / \mathrm{mL}$ (A) and $240 \mathrm{mg} / \mathrm{mL}$ (B) leuprolide loaded 75/25 PLGA microspheres. Microspheres were not exposed to gamma irradiation. Dashed line indicates castration level $(0.5 \mathrm{ng} / \mathrm{mL})$. Dotted line indicates analysis limit of detection $(0.1 \mathrm{ng} / \mathrm{mL})$. Mean $\pm \operatorname{SEM}(n=6)$. Arrow indicates days of dosing.

In vitro release of microspheres loaded with bremelanotide are described in Supplementary Fig 6. Initial burst release was slightly high ( $40 \%)$ than leuprolide (Fig. 2A) followed by continuous release for more than 1 month.

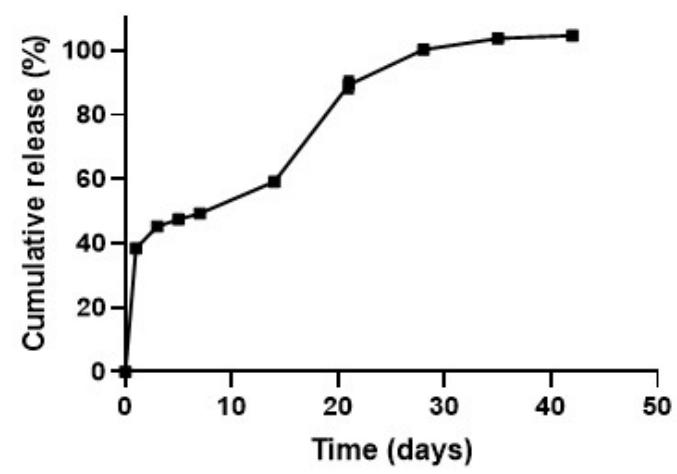

Supplementary Figure 6. Cumulative in vitro release of bremelanotide (8.37 w/w\% load) from remote loaded PLGA microspheres.

Giles et al. 
Figures
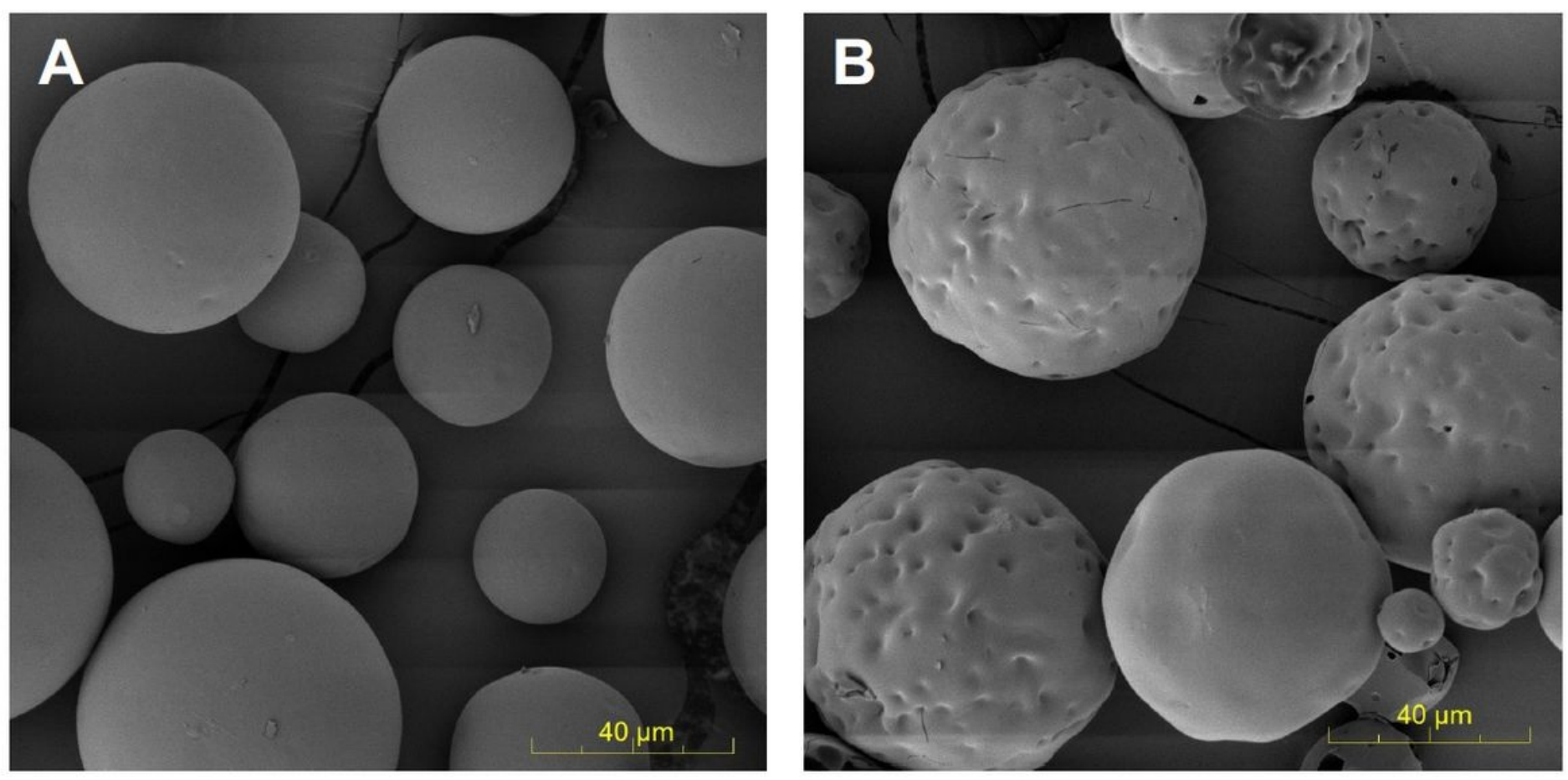

\section{Figure 1}

Scanning electron micrographs of (A) blank PLGA Microspheres and (B) the blank microspheres remoteloaded with octreotide. 


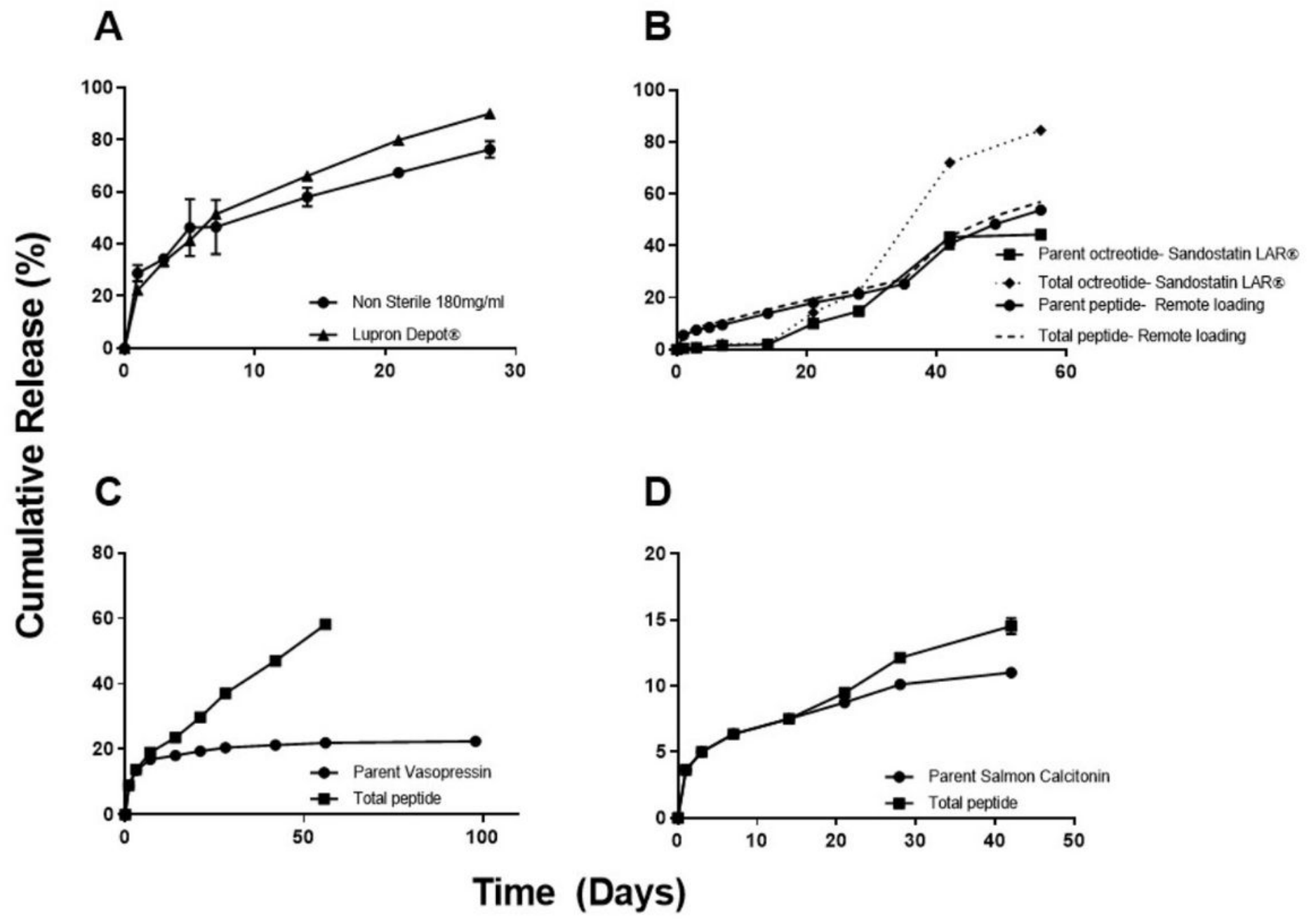

Figure 2

Cumulative in vitro drug release from remote-loaded PLGA microspheres for (A) leuprolide compared to Lupron Depot®, (B) octreotide compared to Sandostatin LAR® (SLAR), (C) vasopressin, and (D) salmon calcitonin. All remote-loaded microspheres were from non-sterile blank PLGA and from $180 \mathrm{mg} / \mathrm{ml}$ peptide solution. Parent and total peptide release listed for specific peptides not fully stable in the polymer. SLAR control data from Beig et al. 19 


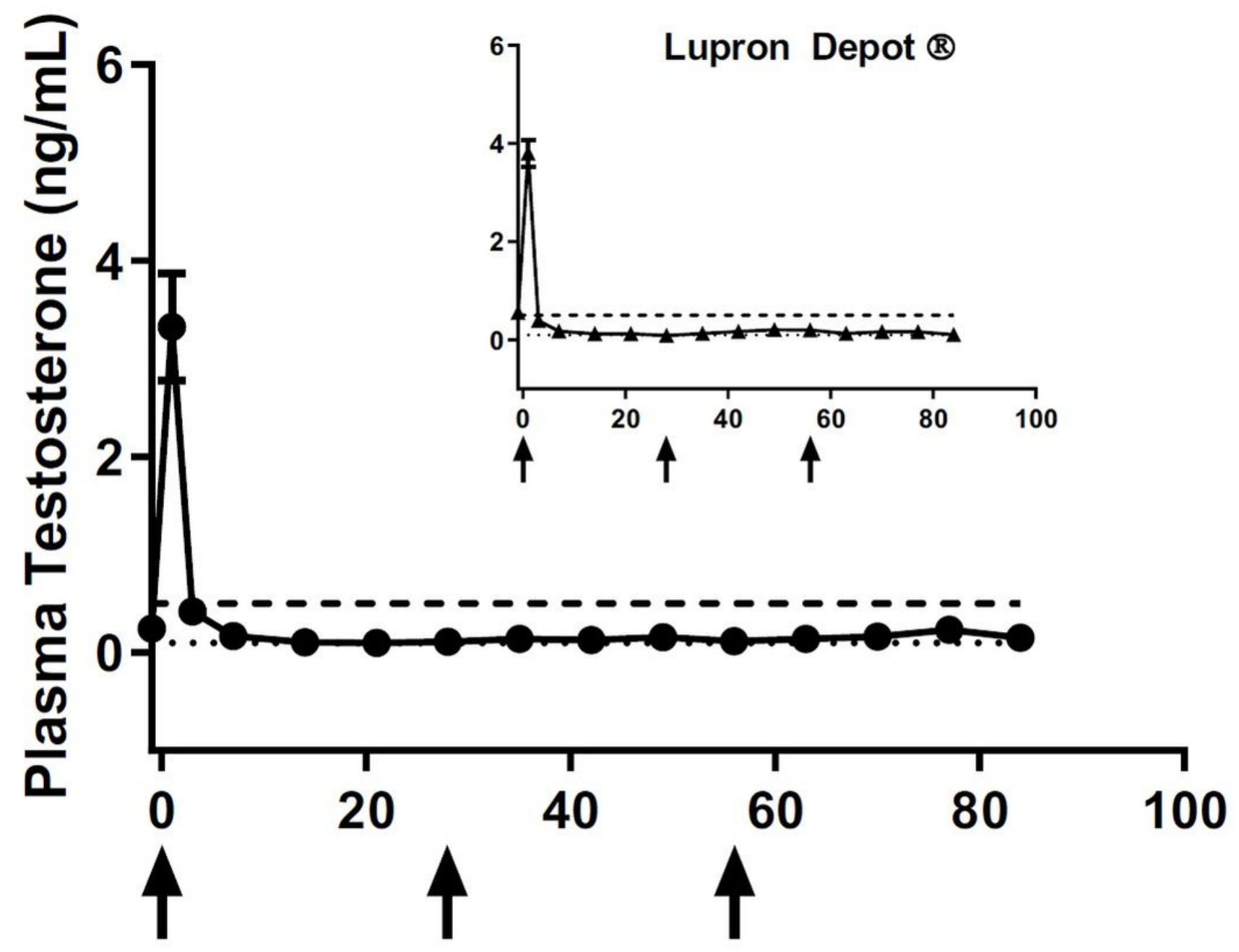

Figure 3

In vivo plasma testosterone levels of male Sprague-Dawley rats administered 3 monthly doses of remoteloaded leuprolide PLGA microspheres compared to equivalent 1-month Lupron Depot ${ }^{\circledR}$ administration (inset). Dashed line indicates castration level $(0.5 \mathrm{ng} / \mathrm{mL})$. Dotted line indicates analysis limit of quantitation $(0.1 \mathrm{ng} / \mathrm{mL})$. Mean \pm SEM $(\mathrm{n}=6)$. Arrow indicates days of dosing. Remote-loaded microspheres were from $240 \mathrm{mg} / \mathrm{mL}$ leuprolide in PLGA microspheres previously exposed to gamma irradiation. 

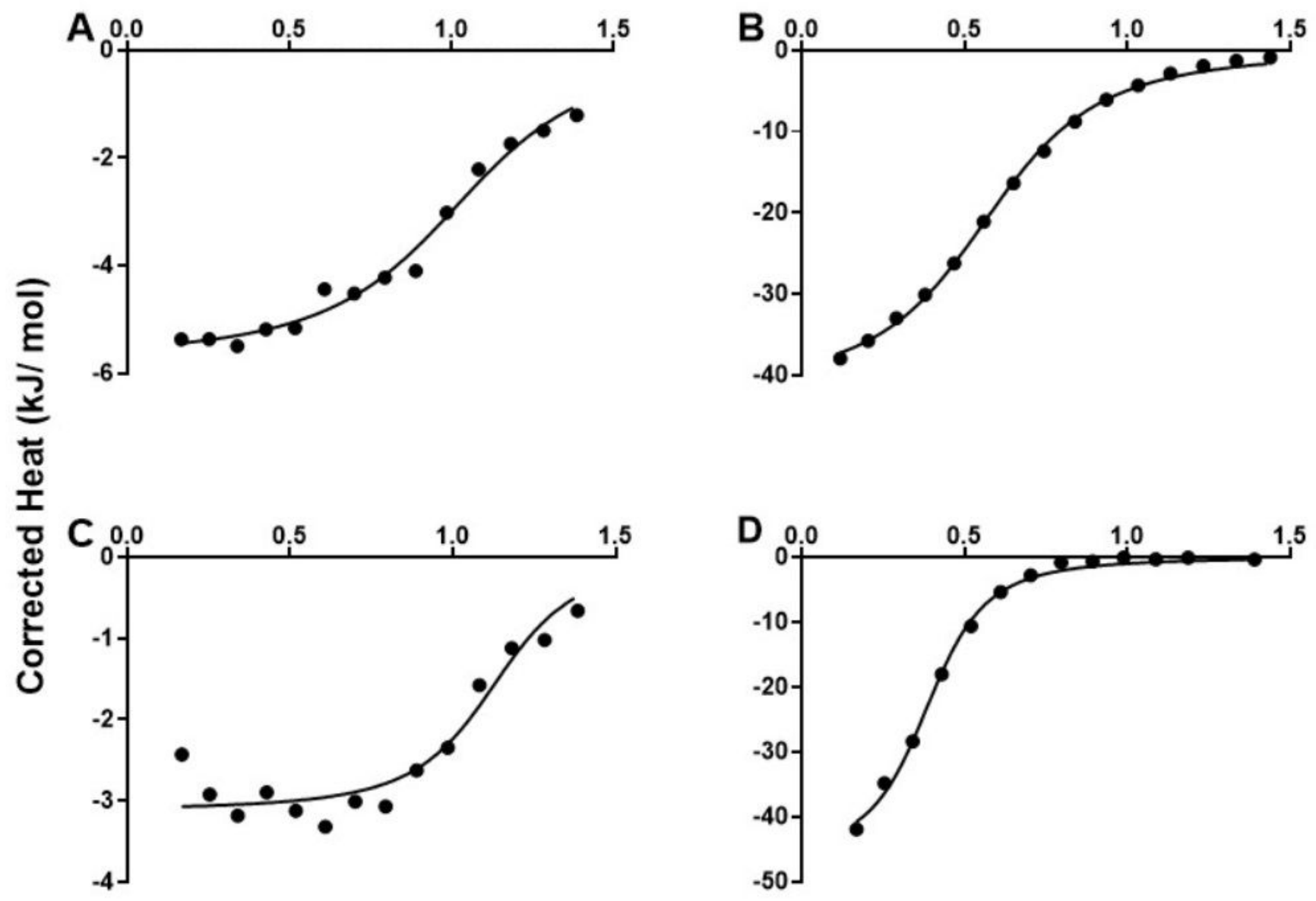

\section{Moles Peptide/ Moles PLGA-COOH}

Figure 4

ITC thermograms of the binding of leuprolide (A), octreotide (B), vasopressin (C), and salmon calcitonin (D) to $75 / 25$ PLGA-COOH in DMSO. Data shown as heat released per molar ratio of peptide to $-\mathrm{COOH}$ groups of PLGA. 

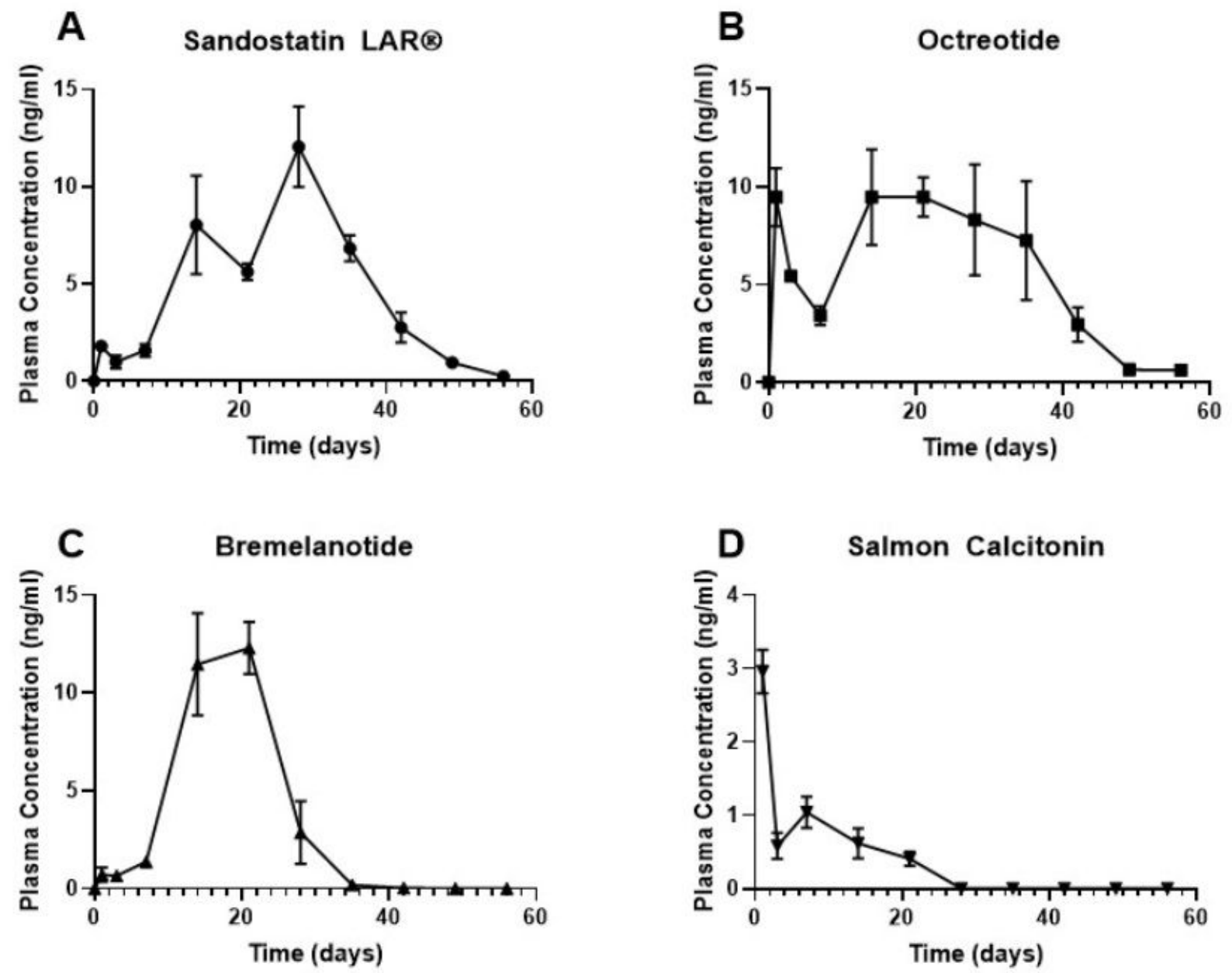

Figure 5

Pharmacokinetics after single subcutaneous injections of Sandostatin LAR® $(A)$, and remote-loaded microspheres containing octreotide (B), bremelanotide (C) and salmon calcitonin (D) in male SpragueDawley rats. Rats in the octreotide and bremelanotide groups were administered a dose of $18 \mathrm{mg} / \mathrm{kg}$. Rats in the salmon calcitonin group were dosed at $4 \mathrm{mg} / \mathrm{kg}$. Mean \pm SEM $(n=4)$. 